Portland State University

PDXScholar

$10-1975$

\title{
Martin Luther King, Jr. and his times: A multi-media script
}

Robert D. Rosenkranz

Portland State University

Follow this and additional works at: https://pdxscholar.library.pdx.edu/open_access_etds

Part of the Social History Commons, and the United States History Commons Let us know how access to this document benefits you.

\section{Recommended Citation}

Rosenkranz, Robert D., "Martin Luther King, Jr. and his times: A multi-media script" (1975). Dissertations and Theses. Paper 2409.

https://doi.org/10.15760/etd.2406

This Thesis is brought to you for free and open access. It has been accepted for inclusion in Dissertations and Theses by an authorized administrator of PDXScholar. Please contact us if we can make this document more accessible: pdxscholar@pdx.edu. 
AN ABSTRACT OF THE THESIS OF Robert D. Rosenkranz for the Master of Arts in Speech Communication presented October 20, 1975 .

Title: Martin Luther King, Jr, and His Times: A MultiMedia Script.

APPROVED BY MEMBERS OF THE THESIS COMTITIMEE:

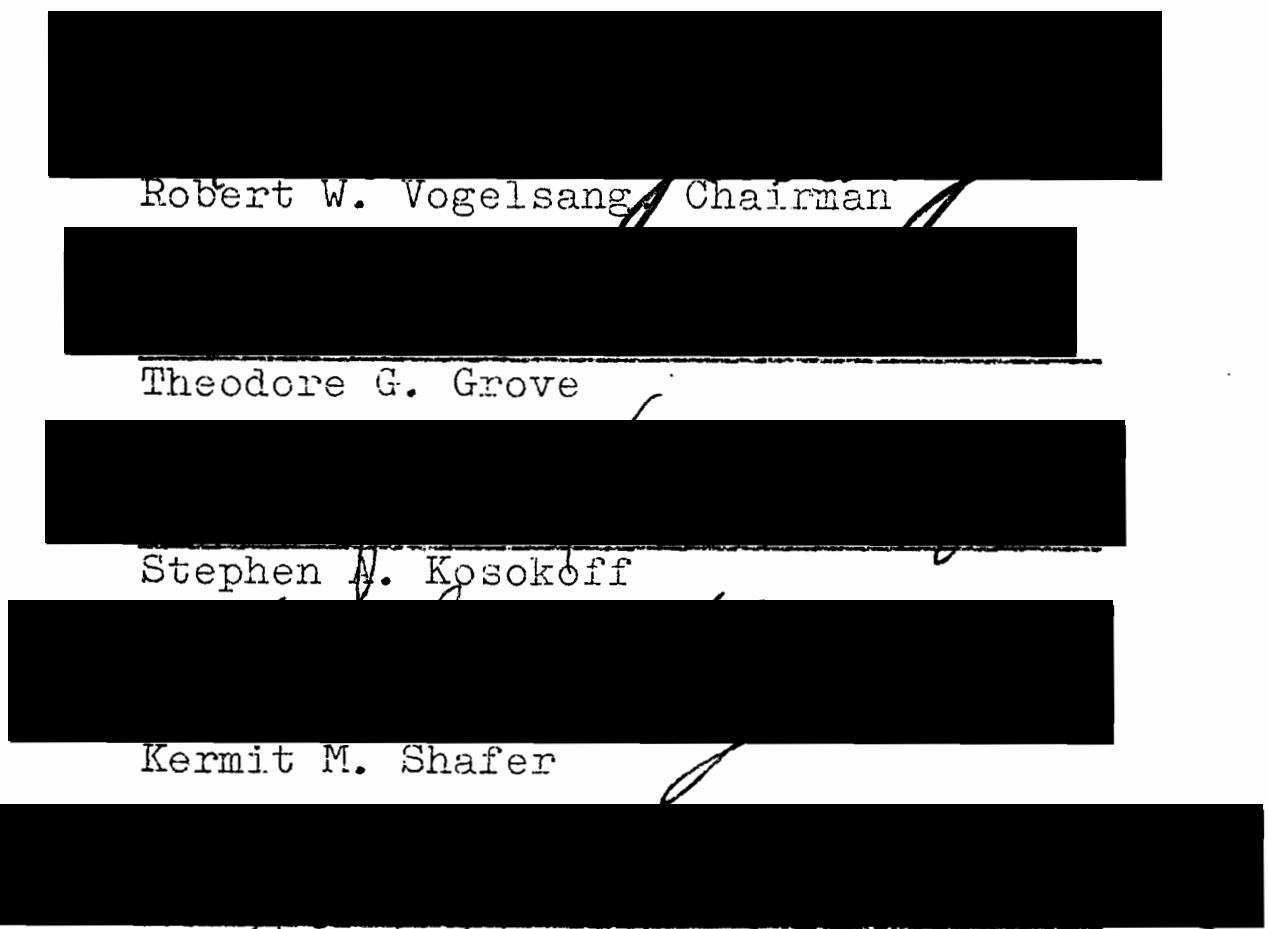

Kermit M!. Shafer

The objective of this thesis it to create a broad perspective of Martin Iuther King, Jr. and his times by placing him and his goal of creating the "belovec comunity" 
to the test of his environment: the feelings and behavior of those people whose hearts and habits he struggled to change or direct.

In order to achieve this, this multi-media script, based in history, places King in contrasting settings. Act I finds King in Montgomery where with a great deal of support he wins over vocal southern segregationists in court. In contrast, Act II takes place in the Lawndale slums of Chicago where King finds sparse support and an elusive northern power structure.

Each scene can be described in terms of stresses Martin Iuther King, Jr. or those whose lives he touched face:

$$
\text { ACT I, SCENE I }
$$

As a boy Martin Iuther King, $\mathrm{Jr}$. is told by a white playmate that he's "gettin' too growd to play with niguhs." ACT I, SCENE 2

Martin Iuther King, Jr. speaks for a Christian and non-violent protest.

ACT I, SCENE 3 AND SCENE 4

Montgomery blacks are nearly unanimously supporting the Montgomery bus boycott. 
ACT I, SCENE 5

A white northern representative for the bus company is convinced by the white Montgomery political and religious structure that in the interest of the bus company he must stand against the boycotters.

\section{ACP I, SCENE 6}

The United States Army trains James Earl Ray in violence.

$$
\text { ACT I, SCENE } 7
$$

Martin Iuther King, Jr. faces white political and theological opposition in Montgomery.

$$
\text { ACT I, SCENE } 8
$$

The home and family of Martin Iuther King, Jr. is bombed. King disperses the resulting angry mob.

$$
\text { ACT I, SCENE } 9
$$

Martin Luther King, Sr. pleads with Coretta and Martin that they leave Montgomery.

$$
\text { ACT I, SCENE } 10
$$

The United States Supreme Court rules bus segregation laws in Montgomery are unconstitutional. 
ACT II, SCENE I

Events indicate that Martin Iuther King, Jr. faces an elusive power structure in Chicago.

$$
\text { ACT II, SCENE } 2
$$

This scene establishes that James Earl Ray was raised in poverty.

$$
\text { ACT II, SCENE } 3
$$

Coretta faces ghetto apathy.

$$
\text { ACT II; SCENE } 4
$$

City hall officially attacks some landlords who are violating building codes. Meanwhile, unofficially, it instructs its allies to attack the legality of Dr. King's trusteeship.

$$
\text { ACT II, SCENE } 5
$$

A Chicago court enjoins Dr. King from withholding rent.

$$
\text { ACT II, SCENE } 6
$$

Martin faces a young ghetto black who wants ghetto problems solved now by any necessary means, violence included. Edited writings of King and edited speeches of Malcolm $X$ are included in this scene. 
ACT II, SCENE ?

King marches non-violently. In Memphis his non-violent march turns violent. There, James Earl Ray assassinates Martin Iuther King, Jr.

ACT II, SCENE 8

This edited speech, "I Have A Dream," stresses Martin Luther King's vision and hope for a "beloved community."

Thus Martin Luther King, Jr. and his times are viewed broadly in the contrasting environments of. two acts, and in a variety of stresses he faces or brings to the surface in diverse scenes.

Research material on Martin Iuther King, Jr. is abundant. Initially biographies about and books and speeches by Martin Iuther King were read. Settings and characters King would face were chosen. Then more specific research was undertaken covering films, newspaper and magazine articles, and dissertations. This research related to the settings of Montgomery, Memphis, and Chicago. It also covered specifically the characters James Earl Ray, Coretta Scott King, and Malcolm $X$.

Since this work is a thesis and not solely a play, extensive references are provided so that the reader may distinguish the historical basis of the thesis from the author's use of dramatic license. For easy and necessary reference a page of footnotes follows each page of script. 
MARTIN LUTHER KING, JR. AND HIS TIMES:

A MULTI-MEDIA SCRIPT

by

ROBERT D. ROSENKRANZ

A thesis submitted in partial fulfillment of the requirements for the degree of

\author{
MASTER OF ARTS \\ in \\ SPEECH COMIUUNICATION
}

Portland State University

1975 
TO THE OFFICE OF GRADUATE STUDIES AND RESFARCH:

The members of the Committee approve the thesis of Robert D. Rosenkranz presented October 20, 1975.

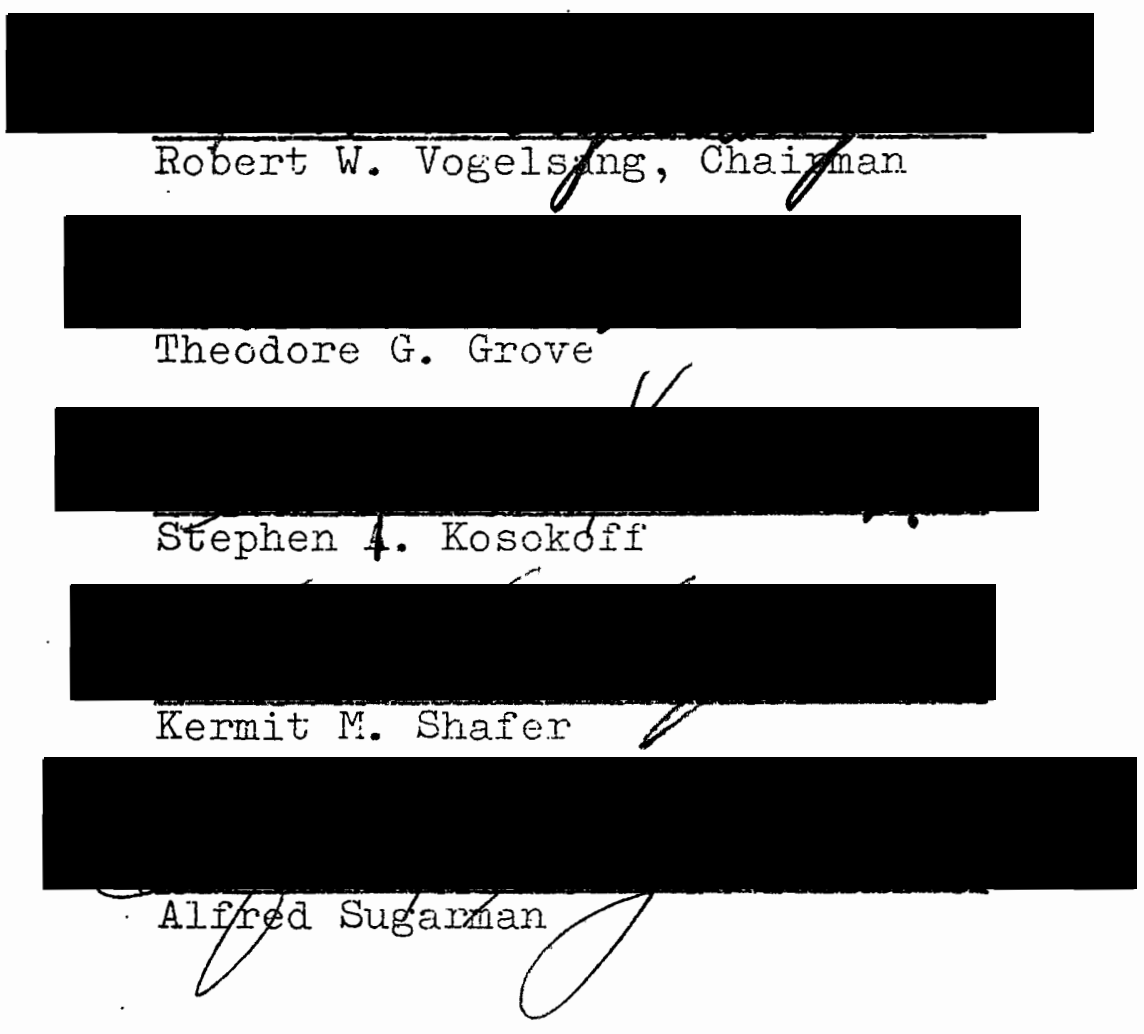

APPROVED :

Robert W. Vogelsarg, Chairmaf, Department of Speech
Communication

Rifhard B. Halley, Acting Dekn of Graduete Studies and 


\section{ACKNOWLEDGMENTS}

I wish to thank my wife Janice for sacrificing some of her personal goals so that I might write and pursue scholastic endeavors. Her sacrifice is a foundation of this work.

I never had the pleasure of meeting Martin Luther King, Jr. in life. But he lives in history. I think I know him there. And yet, I sense there is more to the man than historians and those close to him have allowed us. True, Martin Luther King, Jr. was a man. But he was nearly a rose. The world will thank him for his vision of a "beloved community."

Finally I thank Baha'u'llah whose teachings have cleared my vision in matters of race. A feeling for racial unity is essential to any unfettered perception of Martin Luther King, Jr. and his times. 
TABLE OF CONTENTS

PAGE

ACKNOWLEDGMENTS • • • • • • • • • • • • • •

iii

INTRODUCTION • • • • • • • • • • • • • • • 1

MULTI-MEDIA SCRIPT WITH REFERENCE WORK $\bullet \cdot \cdot \cdot \cdot$

Martin Luther King, Jr. and His Times . . •

BIBLIOGRAPHY • • • • • • • • • • • • • 


\section{INTRODUCTION}

In the past, scholarly works have dealt with Martin Iuther King, Jr. as a preacher, ${ }^{I}$ a non-violent strategist, ${ }^{2}$ a politician, 3 and a champion of the "beloved community." (". . King conceived the Beloved Community in terms of an integrated society wherein brotherhood would be an actuality in every aspect of social life." In 1957 in the Newsletter of the Southern Christian Leadership Conference King wrote, "The ultimate aim of SCIC is to foster and create the 'beloved community' in America where brotherhood is a reality ... ." $)^{4}$ Martin Luther King, Jr. was each of these. But he was more. For he was the composite of all of them. He was a man who struggled to construct the "beloved community" by his many talents in a competitive and sometimes unkind environment. The purpose of this thesis is to reflect historically a more complete Martin Luther King, Jr. by placing him and his goal of creating the "beloved community" to the test of his environment: the feelings and behavior of those people whose hearts and habits he struggled to change or direct. 5 The structure chosen to attain the purpose of this thesis is a drama rooted in research.

After general research about Martin Luther King which consisted of reading most of the books he wrote $6,7,8,9$ and 
many of the biographies about him, ${ }^{10}$ the writer arrived at the following conclusions:

1. A dramatic work attempting to portray the conflicting and supporting beliefs and feelings of the personalities Martin Luther King, Jr. faced would require a minimum of eleven characters as follows:

Martin Luther King, Jr.

Coretta Scott King--a mother, wife, and supporter of the Negro non-violent struggle.

The Reverend Martin Luther King, Sr. whose way of life influenced the beliefs of Martin Iuther King, Jr. ${ }^{1}$

A white southern reverend who as a literal interpreter of the Bible was opposed to the Afro-American social application of the Bible. Consequently he was theologically opposed to Martin Iuther King, Jr.

A white southern, political, racist, opponent such as Mayor Gayle or Bull Conner.

A white practical businessman more dedicated to his professional security than to the establishment of the "beloved community" through the methods of Martin Iuther King, Jr.

An old black poor northern woman whose intial reaction reflects ghetto apathy when she is faced with Martin Luther King's remedy for black ghetto problems.

A black-power advocate who believes non-violence is unsuccessful. 
Someone who reflects southern black pride such as Rosa Parks.

An "antagonist" James Earl Ray, who was raised in poverty, ${ }^{12}$ trained in violence, ${ }^{13}$ and who, according to a friend, was deeply prejudiced against blacks. 14

A character who would point to the ideal of the "beloved community" after the death of Martin Luther King, Jr. 15

2. In a play it's impossible to explore in depth each power structure in each city where Martin Iuther King struggled to create the "beloved community." Each struggle carried its unique characteristics. In Montgomery, buses were boycotted. In Selma, school children were thrown in jail. In Memphis, non-violent marches were disrupted from within. Since few city power structures and representative populations are meaningfully explored in a dramatic thesis, the cities chosen as settings for this work are contrasting cities. Thus Martin Iuther King is seen in at least two quite different settings. The contrasting environments chosen were Montgomery, Alabama, and Chicago, Illinois. A third environment was necessary to end the work--Memphis, Tennessee where James Earl Ray would assassinate King.

Montgomery and Chicago were nearly opposite environments. In Montgomery, King won in the courts. ${ }^{16}$ In Chicago, King lost in the courts. 17 In Montgomery, King faced the blatant southern politician, Mayor Gayle. In his "get-tough" policy Mayor Gayle referred to Negro boycott leaders as 
". - Negro radicals who have split asunder the fine relationships which have existed between the Negro and white people for generations . . " "l8 In Chicago, King faced an elusive white political environment. Malcolm X worded it more dramatically. He said, ". . these Northern crackers smile in your face and show you their teeth and they stick the knife in your back when you turn around."19 In Montgomery, King found nearly unanimous black support. 20 In Chicago, King found black ghetto apathy. After a month in Chicago Hosea Williams said, "I have never seen such hopelessness. The Negroes of Chicago have a greater feeling of powerlessness than any I ever saw." 21

Conclusion 2 complicated conclusion 1. Because there were now two contrasting settings it was probable that more characters than the original minimum of eleven would be required. In a production using actors and actresses on stage as the sole means of portraying characters, numerous characters means numerous entrances and exits. A two-act play with a cast of more than eleven characters and their ensuing action would tend to drag.

So, two alternatives were explored: film and a multimedia stage production. These forms would allow the use of recorded speeches of Martin Iuther King. Furthermore, by cutting from stage characters to characters on film timeconsuming stage action could be either edited or masked. The multi-media form was chosen. A multi-media stage 
production would allow two perspectives of Martin Iuther King: King as a recorded figure in history on audio tapes with slides, and King as a more intimate live actor reacting to the created script situations. Again, contrast was the desired end. Since King could be viewed both as an historical figure and an intimate human being, he would be understood more broadly. The actor King would seem even more intimate when contrasted with the more distant and historical feeling rendered by black and white blown-up slides designed to appear like newsprint. Though grainy two-tone film produced a similar effect in William Goldman's film Butch Cassidy and the Sundance Kid, ${ }^{22}$ a multi-media stage production would offer a greater contrast between stage actor and media effects.

It is essential that any work reflecting an historical figure be based in research. But to what extent? Where does research end and dramatic license begin? This author believes a valid end of both research and drama is truth. It is true in life, and therefore should be true in drama, that once a character's personality is established it cannot change without cause. In this historical dramatic work this truth bears qualification, for the author believes that the personality of the historical character of Martin Iuther King must be established in script as he existed in history. When Martin Iuther King's historical personality exists in script as he did in life the beliefs, traits, and 
characteristics of his script character will tend to direct his actions within the play as it would have in life. However, caution must be taken. This writer believes that an author should not allow an historical figure as recent as Martin Luther King to change within a script if the change is not based on historical causes or evidence of such change in the life of the character. Thus lie the boundaries between the right of the scholar to historical accuracy and the right of the artist to his dramatic license within this historical work.

It follows that the amount of dramatic license allowed varies with the historical nature of the character. The writer allowed himself little dramatic license with the historical figures of Coretta Scott King, Martin Iuther King, Sr., and Martin Iuther King, Jr. except when conversation was adapted to fit the needs of the staged scene and situation. Two more characters fall into this category to a less accurate degree, Mayor Gayle and James Earl Ray. Because of a lack of documented evidence as related to the scenes in which these two characters appear; more has been left to speculation. Yet, their characters and the dramatic situations they faced are founded in research.

Some characters are composites of several historical figures. Cramer, the Old Black Southern Woman, and Jimmy are such characters. Cramer has elements of two historical Montgomery figures: Crenshaw, the attorney for the bus 
company, and C. K. Totten, the northern emissary for the bus company. Their position on the Montgomery bus boycott was similar if not identical. King said, "If Totten could have miraculously acquired a southern accent, and spoken without being seen. I would have sworn that he was Jack Crenshaw. "23 The Old Black Southern Woman existed. Her words are paraphrased for dramatic effect in the Montgomery act when she says, "Used tah be mah soul was tired and mah feets... they was rested. Now mah feets tired... but mah soul. It's ah restin'." Her documented words were: "It used to be my soul was tired and my feets rested. Now my feets tired, but my soul is rested." 24 Later at the end of the Montgomery act she appears again. King read to the courtroom audience, "The United States Supreme Court today unanimously ruled bus segregation unconstitutional in Montgomery, Alabama." And someone from the back of the courtroom shouted, "God Almighty has spoken from Washington."25 However, in this work the Old Black Southern Woman is given these lines.

Jimmy and Iucille as portrayed in Act I, Scene $I$ are composite characters. Jimmy contains characteristics of James Earl Ray. Like Jimmy, James Earl Ray was poor. 26 Although James Earl Ray may not have been taught racial prejudice by his mother Iucille, he was ". . prejudiced to the point that he hated to see a colored person breathe." 27 However, unlike Jimmy, James Earl Ray was raised in a town 
which did not have a Negro resident. 28 In this work Jimmy represents in addition to James Earl Ray a boyhood playmate of Martin Iuther King, Jr.'s. Martin as a boy was told by a mother of two of his white playmates that her children were getting too old to play with "Niggers." Martin was bewildered. 29 And so Iucille directly and James Earl Ray by analogy play a racial confrontation they did not play in its specifics in their lives. James Earl Ray was prejudiced. It follows that Iucille did not successfully teach James Earl Ray that the color of a person's skin is no basis for a value judgment. Probability justifies the use of dramatic license. For the truth is that had Iucille and James Earl Ray lived the racial confrontation in this work, the scene would have played much like it did.

Other characters are based on the known beliefs, attitudes, and characteristics of types of people Martin Iuther King faced. More dramatic license is justifiable when using these characters because they did not specifically exist in history. Consequently Martha, who initially represents black ghetto apathy ${ }^{30}$ can have a distinctive personality sculptured to the artistic needs of this thesis. And she can change her apathetic mind based on an artistically manufactured element of her personality--love for her son. Reverend Danker represents the theological opposition King faced. In this work, Reverend Danker believes that the job of the minister is to lead souls to God, not to get involved 
in transitory social problems. Dr. Frazier, an outspoken segregationist, challenged Dr. King with this belief. 31 The businessman's mind of Baird in the Chicago act is similar to that of Cramer in the Montgomery act. Randel, although completely a fictitious character, becomes an advocate of black power after giving Martin Iuther King an opportunity to prove the value of non-violence as a means to eliminating black ghetto social problems. King wrote of black power: "Beneath all the satisfaction of a gratifying slogan, black power is a nihilistic philosophy born out of the conviction that the Negro can't win."32 In this work as in his life Martin Iuther King left the march in Memphis when it turned violent. 33 The historically based characteristics of the fictional characters Martha, Baird, and Randel are essential to the Chicago ghetto act.

In conclusion, because of the need for dramatic license the script is not pure history. And because of the imperfections of authors and audiences no work is a fitting reflection of Martin Luther King, Jr. Ultimately the responsibility of interpretation is shared between author and audience. Therefore, in a thesis the author is obliged to aid the reader by identifying in footnotes the historical basis upon which he justifies the use of dramatic license. For easy reference a page of footnotes follows each page of the script. Footnotes on any given page refer to the preceding page of script. 
Any references in this introduction to characters and what they mean or seem to do must be viewed as the author's opinion of the script and nothing more. 
Notes

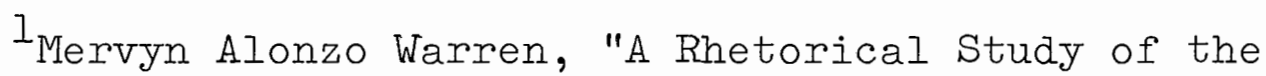
Preaching of Doctor Martin Luther King, Jr., Pastor and Pulpit Orator" (Ph.D. dissertation, Michigan State University, 1966).

${ }^{2}$ Lois Diane Wasserman, "Martin Luther King, Jr.: The Molding of Non-violence as a Philosophy and Strategy" (Ph.D. dissertation, Boston University, 1972).

3 Hanes Walton, Jr., "The Political Philosophy of Martin Iuther King, Jr."' (Ph.D. dissertation, Howard University., 1967).

${ }^{4}$ Kenneth I. Smith and Ira G. Zepp, Jr., Search for the Beloved Community: The Thinking of Martin Luther King, Jr. (Pennsylvania: Judson Press, 1974), p. 120.

5 Martin Luther King, Jr., "A Long Way to Go," in The Voice of Black Rhetoric, ed. Arthur I. Smith and Stephen Robb (Boston: Allyn and Bacon, 1971), p. 197.

6 Idem, Stride Toward Freedom (New York: Harper and Row, 1958).

7 Idem, Strength to Love (New York: Harper and Row, 1963). $1964)$.

${ }^{8}$ Idem, Why We Can't Wait (New York: Harper and Row,

${ }^{9}$ Idem, Where Do We Go From Here: Chaos or Community? (New York: Harper and Row, 1967).

10 Two biographies I relied on heavily are: David I. Lewis, King, A Critical Biography (New York: Praeger Pub., 1970); Coretta Scott King, My. Life With Martin Iuther

King, Jr. (New York: Holt, Rinehart, and Winston, 1969).

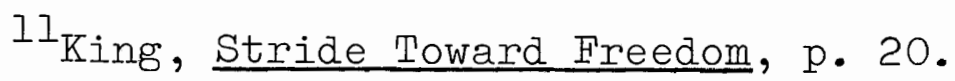

${ }^{12}$ Clay Blair, Jr., The Strange Case of James Earl Ray

(New York: Bantam Books, 1969), p. 21.

13 Ibid., p. 34. $\quad{ }^{14}$ Ibid., p. 59.

15 This character was replaced by an edited version of Martin Iuther King's speech I Have a Dream. 
$16_{\text {King }}$, Strength to Love, p. 50.

17 William Robert Miller, Martin Luther King, Jr.

(New York: Weybright and Taliey, 1968), p. 238.

18 Lerone Bennett, What Manner of Man (Chicago: Johnson Pub., 1968), p. 68 .

19 Malcolm X, "Message to the Grass Roots," in Malcolm X Speaks, ed. George Breitman (New York: Grove Press, 1965), p. 16.

$2 \mathrm{O}_{\text {Miller, }}$. 38 .

${ }^{21}$ David I. Lewis, King: A Critical Biography

(New York: Praeger Pub., 1970), p. 313.

22 William Goldman, Butch Cassidy and the Sundance Kid (New York: Bantam Books, 1969), p. 1 .

23 Bennett, p. 68 .

${ }^{24}$ Coretta Scott King, My Life With Martin Iuther King, Jr. (New York: Holt, Rinehart and Winston, 1969), pp. 120-

$25 \mathrm{King}$, Strength to Love, p. 50.

26 Blair, p. 21. 27 Tbid., p. 59. 28 Ibid., p. 25.

29 Robert M. Bleiweiss, ed., Marching to Freedom

(New York: The New, American Library, 1969), pp. 38-39.

$30_{\text {Lewis, p. } 313 .}$

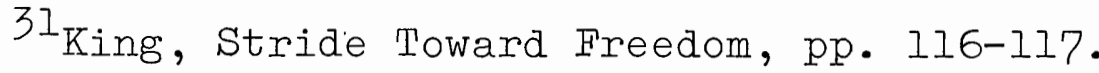

32 Idem, Where Do We Go From Here, p. 44.

33 Miller, p. 271. 
MARIIN IUTHER KING, JR. AND HIS TIMES 
ACT I

SCENE I

Sitting downstage, center, JIMMY (an eight year-old lean, white boy) is whittling a stick into a rifle. His costume shows he's poor. He looks unkempt.l We know he is carving a rifle because the butt is already whittled. MARTY enters. MARTY (MARTIN LUTHER KING) is eight too but better dressed than the impoverished wretch JIMIMY. (A partial analogy can be drawn between JIMMY and JAMES EARI RAY. $2,3,4$ )

MARTY: Hi, Jimmy. Whatcha whittling?

(JIMMY glances up at MARTY uneasily then recedes to carving his rifle.)

MARTY: What's the matter? You're as mute as the dead in the county graveyard. Just as spooky too. Hyaah!

\section{(JIMIY starts.)}

JIMIY: Hey!

IIARTY: See.

JIMYY: Quit clownin' will yah.

MARTY: You sick?

JIMIMY: It's got nothin' tah do with bein' sick or well. I'm busy whittlin'. See? Ain't got time fer play no more.

(MARTY snatches the rifle.)

JIMMY: Gimme that. . I can get it anyway. You know I'm quicker.

MARTY: You talk pretty. 
${ }^{1}$ Clay Blair, Jr., The Strange Case of James Earl Ray

(New York: Bantam Books, 1969), p. 21.

The Ray family chronicle is the classic example of the American family at its worst: burdened with grinding poverty, bad luck, an embittered, shiftless father, and a mother unable to cope.

$2_{\text {Ibid. , p. } 59 .}$

In the Deep South, according to Rife, James Earl Ray expressed a deep-seated hatred for black people. "He was prejudiced to the point that he hated to see a colored person breathe" Rife says. "You could gather from his conversation that if it was up to him, there wouldn't be any colored people. They would either be shipped back to Africa or disposed of in some way."

$$
3 \text { Ibid., p. } 126 .
$$

If the bartenders along Hollywood Boulevard can be believed . - They recall Ray-Galt, [alias James Earl Ray] belting screwdrivers at the bar, loudly denouncing Negroes. When a girl in one bar told him Negroes were "good people," Ray-Galt grabbed her arm and wrenched her to the door, shouting: "I'll drop you off in Watts and we'll see how you like it there."

$$
{ }^{4} \text { Ibid., p. } 25 .
$$

- the town had never had a Negro resident, and hasn't had to this day. "The only time we ever saw a nigger," says an old-timer, "was when they was building the highway. But they kept them in a special camp." The lily-white character of Ewing has prompted the newspaper in a nearby town, La Grange, to label Ewing "Little Dixie." 
JIMMY: Oh Jah.

(JIMMY darts at MARTY. MARTY sidesteps him. But with a quick reach JIMIY trips MARTY. The two playfully strugg.le over the rifle. Too small to retrieve it by force, JIMMY starts tickling MARTY, weakening MARTY to laughter. MARTY drops the rifle. JIMMY, laughing himself now, continues tickling MARTY for the sheer joy of it. Cold-eyed, JIMMY'S mother LUCIIIE enters, stage right. She is the essence of southern white poor.5 Seeing her, JIMMY ceases scuffling, while MARIY takes advantage of the opportunity to gain a more strategic wrestling position.)

LUCILUE: Let go, Martin.

MARTY: (obeying) Hi, Missus Raines. Just playing. LUCILUE: Jimmy, get up.

(Close-mouthed and humiliated, JIMMY rises and brushes himself off.)

MARTY: We have our old clothes on. My mother says I can wrestle if I have...

IUCIILE: You tell Martin, Jimmy?

MARTY: Tell me? What you ...

IUCIIJE: Hush Martin. Jimmy is gonna speak. Did you tell Martin?

JIMTY: No, ma.

IUCILLE: You gotta be truthful. I know Martin's been your friend. But yer pretty near growd now, son. An Marty he's pretty near growd too. Time tah be a man. Time tah be honest with Marty. You owe him that. Understand? . . Understand:

JIMIY: Yes, ma.

LUCIIUE: Now look em in the eye. Straight in his eye . . That's it. Tell em outright. Tell em what is.

JIMMY: My paw says . . 
${ }^{5}$ Clay Blair, Jr., The Strange Case of James Earl Ray (New York: Bantam Books, 1969), p. 21 .

The Ray family chronicle is the classic example of the American family at its worst: burdened with grinding poverty, bad luck, an embittered, shiftless father, and a mother unable to cope. 
LUCILLE: Ain't cause paw said it son. You know that.

(Pause. JIMMY looks at his feet.)

JIMIY: Can't play.

MARTY: Huh?

(JIMIY looksup at MARTY.)

JIMMY: Can't play with yah no more . . nevuh.

(Dazed, MARTIN starts his turn to walk away.)

LUCIILE: Wait Martin. Jimmy, he ain't finished.

(MARTIN'stops. He looks at JIMIMY.)

LUCIILE: (continues) T'ell em why Jimmy.

JIMIY: Ah maw, he knows.

LUCILLE: How could he? You ain't told him.

JIMIMY: Mạ please.

LUCILLE: Tell him tah his face. It's what God wants... You don't tell em Jimmy and Paw's gonna take the belt tah you!

(J IMIYY fidgets.)

JIMMY: $6^{\text {Gettin' }}$ niguhs.
. gettin' too growd to play with

LUCILLE: You understand Martin? (Pause. LUCILLE grows somewhat sympathetic and gives the advice motherly.) Ask at home boy. Yer mah'll learn yah. Come Jimmy. 
$6_{\text {Robert M. Bleiweiss, ed., Marching to Freedom }}$ (New York: The New American Library, 1969), pp. 38-39.

Among his [Martin's] playmates were the two sons of a white grocery store owner. The day came when the boys' mother' said that they could not play with Martin anymore. . . the woman blurted out, "They're getting too old to play with niggers." Martin was bewildered. 
(LUCILIE begins exiting guiding JIMIY ahead of her. She turns and calls to MARTIN.)

LUCIILE: Ask at home boy.

(EXit LUCILLE and JIMMY, stage right. MARTY watches them exit, then bewildered, exits stage left. 
ACT I

SCENE 2

\section{Video (slides)}

\section{Slide 1: MRS. ROSA PARKS on bus.}

Slide 2: MRS. ROSA PARKS being arrested.

Cross fade from slide 2 to Slide 3': Grainy picture of MARTIN LUTHER KING speaking.

\section{Audio}

MARTIN on tape: Just the other day one of the fine citizens of our community Mrs. Rosa Parks was arrested because she refused to give up her seat for a white passenger.1

Fade up crowd sounds for Holt Street Baptist Church speech.2

On audio tape:

MARTIN: (crowd noise and comments in background) My friends, we are certainly very happy to see each of you out this evening. We're here this evening for serious business. We're here in a general sense because first and foremost, we are American citizens, and we are determined to acquire our citizenship to the fullness of its meaning. We are here also because of our deep-seated belief that democracy transformed from thin paper to thick action is the greatest form of government on earth. But we are here in a specific sense because of the bus situation in Montgomery. We are here because we are determined to get the situation corrected. Mrs. Rosa Parks is a fine person, and since it had to happen, I'm happy that it happened to a person like Mrs. Parks, and nobody can doubt the height of her character . . the boundless reach of her integrity . . . the depth of her Christian commitment and devotion to the teachings of Jesus. You know, my friends, there comes a time when people get tired of being trampled over by the iron feet of oppression. There comes a time my friends when people get tired of being plunged across the abyss of humiliation, when they experience the bleakness of nagging despair. There comes a time when people get tired of being pushed out of the glimmering sunlight of last July and left standing amid the piercing chill of an Alpine November. 3

We are here this evening to say to those who have mistreated us so long that we are tired--tired of being 
${ }^{1}$ Martin Luther King, Jr., interview on film, From Montgomery to Memphis, Bailey Film Association, 1969, $16 \mathrm{~mm}$ sound on film.

${ }^{2}$ Donald H. Smith, "Martin Iuther King, Jr.: In the Beginning at Montgomery," Southern Speech Journal, XXXIV (Fall 1968): 12.

By 7:30 p.m. all seats of the Holt Street Baptist Church were taken. Including those standing about one thousand Negroes packed the church. Outside, a crowd estimated at five thousand by the Advertiser and said to be closer to seven thousand by on-thespot observers, listened to the proceedings by means of loud speakers.

${ }^{3}$ Tbid., pp. 12-15. 
segregated and humiliated; tired of being kicked about by the brutal feet of oppression. 4

We are not afraid of what we're doing because we're doing it within the law. We are not wrong in what we are doing. If we are wrong, the Supreme Court of this nation is wrong. If we are wrong, the Constitution of the United States is wrong. If we are wrong, God Almighty is wrong. If we are wrong, Jesus of Nazareth was merely a--Utopian dreamer who never came down to earth. 5 - . In our protest there will be no cross burnings. No white person will be taken from his home by a hooded Negro mob and brutally murdered. There will be no threats and intimidation. We will be guided by the highest principles of law and order. . . Our methods will be that of persuasion not coercion. We will only say to the people, "Let your conscience by your guide." Our actions must be guided by the deepest principles of our Christian faith. Love must be our regulating ideal. Once again we must hear the words of Jesus echoing across the centuries: "Love your enemies, bless them that curse you, and pray for them that despitefully use you." If we fail to do this our protest will end up as a meaningless drama on the stage of history, and its memory will be shrouded with the ugly garments of shame. In spite of the mistreatment that we have confronted we must not become bitter, and end up by hating our white brothers. As Booker T. Washington said, "Let no man pull you so low as to make you hate him." If you will protest courageously, and yet with dignity and Christian love, when the history books are written in future generations, the historians will have to pause and say, "There lived a great people--a black people--who injected new meaning and dignity into the veins of civilization." This is our challenge and overwhelming responsibility. 6

(Fade out slide.) 
${ }^{4}$ Martin Luther King, Jr., Stride Toward Freedom (New York: Harper and Row, 1958), pp. 61-63.

5 Donald H. Smith, "Martin Luther King, Jr.: In the Beginning at Montgomery," Southern Speech Journal, XXXIV (Fall 1968): 12-15.

$6_{\text {King, pp. } 61-63 .}$ 


\section{ACT I}

\section{SCENE 3}

Fade up lights on living room, stage left. An older MARTIN LUTHER KING (thirties) sits thinking. The dim light passing through the living room window indicates it is dawn. MARTIN reflects restlessly.

MARTIN: Ralph! Ralph Abernathy was there. The Montgomery Improvement Association is Ralph's brain child. He should have been elected President . . No. Ralph's been around too long. He's identified with a particular Negro position. Coretta and I haven't lived in Montgomery long enough to be pigeonholed. It's frightening. Montgomery's a small city. Yet it's Negro leaders are bitterly divided.l like a flash! It happened fast. Nominations for President were opened. Rufus Lewis sounded my name. . Martin King. Someone seconded the nomination . . can't remember who . . . and I was elected President of the M-I-A . . unanimously.2

\section{(A light switches on from the kitchen offstage, upstage} left. Sound of someone pouring coffee.)

MARTIN: If I'd had time to think (shrugs his shoulders) schooled Martin King--or naive graduate. 3 (MARTIN peers out of the window.) Soon. Soon we'll know.

(Clean, neat and dressed, CORA enters, upstage left, with two cups of steaming coffee. MARTIN moves to the table where CORA places the coffee. MARTIN sits down. Nervous, CORA g.lances at her watch.)

CORA: Five-fifty. The bus is almost due. 4

MARTIN: You're anxious.

CORA: Yes . - Martin, you won't be too disappointed. I mean if by some fluke.

MARTIN: Yes. Yes I will • • if 
${ }^{I}$ Lerone Bennett, What Manner of Man (Chicago: Johnson Pub., 1968), p. 65 .

King and others have suggested that King was selected because he was new in the community and was not identified with any faction of the bitterly divided leadership group.

2 Martin Luther King, Jr., Stride Toward Freedom (New York: Harper and Row, 1958), p. 56.

As soon as Bennett had opened the nominations for president, Rufus. Lewis spoke from the far corner of the room: "Mr. Chairman, I would like to nominate Reverend M. L. King for president." The motion was seconded and carried, and in a matter of minutes I was unanimously elected.

3 Ibid.

The action [Martin's election as President of the Montgomery Improvement Association] caught me unawares. It had happened so quickly that I did not even have time to think it through. It is probable that if I had, I would have declined the nomination.

${ }^{4}$ Coretta scott King, My Life With Martin Iuther King, Jr. (New York: Holt, Rinehart and Winston, 1969), p. 115 .

- . at five-thirty the next morning we were up and dressed. . . The first bus was due at six o'clock at the bus stop just outside our house. 
CORA: Shhh. (Pause.) Martin..

MARTIN : Yes.

CORA: How many Negro citizens will be riding the early morning bus? How many will refuse to boycott the

buses.. - despite Rosa Parks, despite their human rights? How many won't walk for their dignity?

(CORA walks to an imaginary window, located between her, and the audience. She looks out.)

MARTIN: The Negro leaders who've been here longer than I say if sixty percent boycott the buses we're fortunate. 5 But are we sixty percent strong?

CORA: Suppose sixty percent of our people-maids and common laborers are willing to walk to work rather than ride buses, would we win?

MARTIN: Umm. We'd do all right.

CORA: There is reason for hope, Martin. Negro cab companies are supporting the boycott. Cab drivers will pick up those who can't walk. They're only charging the cost of a bus ride. 6

MARTIN: Yes.

CORA: And ministers are supporting the boycott.?

MARTIN: Crucial support.

CORA: Events are working in our favor. Remember how concerned we were? We were wondering how we could alert the entire Negro community to the boycott.

MARTIN: I remember.

CORA: And then there it was--in bold type on the front page of the Montgomery Herald. "Negroes to Boycott Buses." A newspaper article written by a white reporter alerted the whole Negro community. 8

MARTIN: It's a positive sign.

CORA: Ed Nixon's saying he knows the newsman who wrote that story. Did Ed leak that story to the newspaper? 
5 Martin Luther King, Jr., Stride Toward Freedom (New York: Harper and Row, 1958), p. 52.

My wife and I discussed the possible success of the protest. Frankly, I still had doubts. Even though the word had gotten around amazingly well and the ministers had given the plan such crucial support, I still wondered whether the people had enough courage to follow. I had seen so many admirable ventures fall through in Montgomery. Why should this be an exception? Coretta and I finally agreed that if we could get 60 per cent cooperation the protest would be a success . . every Negro taxi company in Montgomery had agreed to support the protest on Monday morning. Whatever our prospects of success, I was deeply encouraged by the untiring work that had been done by the ministers and civic leaders. This in itself was a unique accomplishment.

6 Ibid. $7_{\text {Ibid. }}$

${ }^{8}$ David I. Lewis, King: A Critical Biography (New York: Praeger Pub., 1970), p. 53.

- . the acquisition by the Montgomery Advertiser of the text of Mrs. Robinson's leaflet. Martin King believed that an illiterate servant had given her leaflet to her white employer to be read to her. The employer contacted the Newspaper. Nixon, however, dismisses this explanation, for he relates that, before departing on Friday, he had contacted Joe Azbell of the Advertiser. "I knew this reporter very well, "he says. "I talked to him, and I told him, I said, here, you got a chance to do something for Negroes. If you promise you'll play it up strong in your paper Sunday, I'll give you a hot tip." 
MARTIN: That black porter's done a lot for Negroes. I wouldn't say anything against him. Yet, he enjoys spinning CORA: Yes. Still, he is crafty.

MARTIN: Ummmmm. He is that. But the street version has it different. I heard it at a pool hall. They say a white housewife found one of the boycott leaflets. It seems her Negro maid was a little careless and left it in plain sight. Enraged, that blue-eyed housewife telephoned the Montgomery Herald. 9 She was an angel.

CORA: Perhaps the angel was brown-eyed and surnamed Ed... Martin! Martin, come quickly!10

(MARTIN rushes to the window.)

CORA: It's empty.

MARTIN: No one.. not one soul on that bus!ll

(MARTIN hugs CORA.)

MARTIN: One hundred percent God's children, baby:

(And CORA smiles.)

MART IN: I'm going to get Ralph and see what's happening on
the roads. 12

(Exit MARTIN, stage center left. CORA smiles in supreme satisfaction. Lights on CORA fade under and out. She exits to the kitchen, upstage left.) 
9 Ibid.

${ }^{10}$ Coretta Scott King, My Life With Martin Luther King,

Jr. (New York: Holt, Rinehart and Winston, 1969), p. 115.

We had coffee and toast in the kitchen; then I went into the living room to watch. Right on time, the bus came. . . I shouted, "Martin! Martin, come quickly!" He ran in and stood beside me, his face lit with excitement. There was not one person on that usually crowded bus! . . Finally Martin said, "I'm going to take the car and see what's happening other places in the city." 


\section{ACT I}

SCENE 4

The curtain slowly closes as a walk on--an OID BLACK WOMAN carrying a lunch sack--walks slowly across the downstage apron from stage left to stage right towards town. Before she has crossed the stage, three walk ons--college students: a BLACK GIRL, a BIACK BOY, and a WHITE BOY--enter from the same side the OID BIACK WOMAN entered. They move briskly and pass up the OID BLACK WOMAN as they hitchhike across the stage watching cars pass. Just before the BIACK GIRI exits she calls to the OLD BLACK WOMAN who is still crossing the stage at a snail's pace.

BLACK GIRI: Gettin' tired, Grandma! ${ }^{2}$

WHITE BOY: Hey, a ride!

(The three college students exit downstage right, quickly. Meanwhile, the OLD BLACK WOMAN has stopped to get her breath before answering. Peering toward where the college students were the OID BIACK WOMAN mutters:)

OLD BLACK WOMAN: Used tah be mah soul was tired and mah feets.. . they was rested. Now

(She begins walking.)

OLD BLACK WOMAN: (continues) mah feets tired. . but mah soul. It's ah restin'.2

(She continues walking at a snail's pace and she chuckles at the thought a bit. At last she exits, downstage right. open curtain.) 
${ }^{1}$ Coretta Scott King, My Life With Martin Luther King, Jr. (New York: Holt, Rinehart and Winston, 1969), pp. 120-

Somebody asked one old grandmother, coming down the street, if she was not tired. She answered, "It used to be my soul was tired and my feets rested; now my feet's tired, but my soul is rested."

2 Ibid. 


\section{ACT I}

\section{SCENE 5}

Stage right meeting area: two short rows of chairs face each other, arranged for confrontation. Between the rows and upstage is a judge's bench and chair. Centerstage right, MISTER CRAMER, who is a northern businessman, listens. as the very southern MAYOR GAYLE of Montgomery paces the floor.1, 2,3

MAYOR GAYIE: Complications! It's got nothing to do with complications! In this city you are either white or you are black. It's as simple as that. Now if you don't know which color you are, just show your face in that black bar down the street. And when you pick your ass up off the sidewalk you'll know you ain't ah Nigre.

CRAMER: Mayor Gayle, I'm not interested in testing the love ties in this city. What I am solely interested in is ending this boycott. And you ought to be interested in the same thing. Our bus line may fold here in Montgomery because of this boycott. At least we have lines in other cities. You, Mayor, don't. 4

MAYOR GAYIE: What the hell do you mean by that crack:

CRAMER: What's really important here, this community or your lousy pride? Mayor, Montgomery businessmen have already lost more than a million dollars in trade. 5 How much more will they pay for a few seats in the front of the bus?

MAYOR GAYLE: As much as it takes! The whites in this community are staunch in their convictions. We don't give a damn if a Nigre ever rides a bus again if it means that the fine relationship which has existed between Negroes and Whites for generations would change one iota. 6

CRAMER: One million dollars!

MAYOR GAYIE: God knows we've attempted to settle this boycott. We're not at fault here. First we tried to just kinda let it all blow over.? Let them colored people work off their steam. That didn't work. So we tried talkin' it 
$1_{\text {This scene combines two meetings at which Martin }}$ Luther King, Jr. was present in Montgomery. Both covered similar issues. Jack Crenshaw attended only the first. Totten attended only the second.

${ }^{2}$ Martin Iuther King, Jr., Stride Toward Freedom (New York: Harper and Row, 1958), p. 109.

We arrived at the city hall about fifteen minutes before the hour set for the meeting. There we were directed to the Commissioners' Chamber . . soon Thrasher, Hughes, and Trenholm came in and joined us. . . Promptly at eleven the three commissioners-Mayor W. A. Gayle, Commissioner Clyde Sellers, and Commissioner Frank A. Parks--filed in and sat at the table facing us. They were joined by. J. E. Bagley and Jack Crenshaw, representing the bus company, who took seats near one end of the table. Thus the lines appeared to be clearly drawn before the meeting began.

$$
3 \text { Ibid., p. } 114 \text {. }
$$

- . the mayor sent word that he was calling a citizens committee to meet with the bus officials and Negro leaders on the morning of December 17. Over a week had passed since the first conference and the protest had still shown no signs of faltering.

The executive board of the MIA once more met to discuss our position.

$$
4 \text { Ibia., pp. 118-119. }
$$

At the close of the meeting I had my first opportunity to talk face to face with Totten. Almost sheepishly he admitted that the plan we were offering was the one followed by the Mobile City Iines--another company owned by the National City Iines, Inc. "And as far as I am concerned," he said, "it would work very well in Montgomery. But the city commission seems to feel that it will not be acceptable."

${ }^{5}$ David L. Lewis, King: A Critical Biography (New York: Praeger Pub., 1970), pp. 66-67.

By the third month of the boycott, the restricted travel of blacks had resulted in the loss to local merchants of more than $\$$ million. The loss of revenue caused the business community to mobilize. 
${ }^{6}$ Lerone Bennett, What Manner of Man (Chicago: Johnson Pub., 1968), p. 68.

- . [Negro Leaders] have forced the boycott into campaign between whether the social fabric of our community will continue to exist or will be destroyed by a group of Negro radicals who have split asunder the fine relationships which have existed between the Negro and white people for generations. . . What they are after is the destruction of our social fabric. . . The white people are firm in their convictions that they do not care whether the Negroes ever ride a city bus again if it means that the social fabric of our community is destroyed so that Negroes will start riding buses again.

Quoted from Mayor Gayle!'s "get-tough" policy announced Tuesday, January 24.

7 Ibid., p. 68.

In the beginning, white Montgomerians--and many Negro Montgomerians--believed that the boycott would eventually unravel at the seams, with the Negro leaders devouring each other like wounded sharks. 
out. Our White Citizens Council even sat down and tried negotiating with them radical Nigre leaders. Nothin'. Nothin'!

CRAMER: And your White Citizens Council. . did it offer some sort of compromise?

MAYOR GAYIE: Compromise! Mister Cramer, them Nigre leaders aren't interested in compromise. They don't want to end this boycott. They've nurtured this boycott. Them colored people have conjured up an illegal boycott--a lioness deliberately created for the purpose of shredding the social fabric of this community. Compromise! 8

CRAMER: An experienced politician like yourself Mayor is surely aware that a compromise is better than economic suicide.

MAYOR GAYLE: You're half right, Mister Cramer. I am experienced. And my experience tells me that you are new to the South . . to Montgomery. And like all northerners you don't understand her. But me, I've lived and worked her a long time. And I can sense Montgomery. I know when she's sweet and when she's sour. Now... now only revenge will satisfy her.

CRAMER: Your dying city needs life more than revenge.

MAYOR GAYIE: Time's short, Cramer. You have a decision to make. You can do one of two things. You can prolong the boycott by defending Nigres, or you can end the boycott by helping us crush them colored radicals. It's plain enough. In the interest of your bus company it's time you joined us and quit pussy-footing around.

(Enter stage right center, the white REVEREND DANKER. He is meticulously dressed in the garb of the clergy.)

MAYOR GAYIE: Afternoon Reverend. I'm pleased you came.

DANKER: I'm sure you are. But don't foster any illusions of friendship. It's my religion that brought me here.

MAYOR GAYLE: It makes no never mind to me Reverend why you're here, just so we understand each other.

DANKER: Fortunately Mayor our relationship does not depend upon our understanding one another. I understand you Gayle. 
${ }^{8}$ Ibia. 
You're a simple man. But simple men like yourself lack the. spiritual and intellectual depth to understand me. Not understanding but rather the common goal of preventing racial chaos is the basis of our relationship, Mayor.

CRAMER: I . I don't believe I've been introduced.

(DANKER shakes CRAMER'S hand.)

DANKER: I'm Reverend Danker. I'm afraid our Mayor lacks the most basic social amenities.

MAYOR GAYLE: Now look here, Danker . •

DANKER: Reverend Danker! Do you wish my cooperation Mayor? After all you solicited my services.

MAYOR GAYLE: Cut the crap Reverend. The outcome of this meeting means as much to you as it does to me.

DANKER: (to CRAMER) Yet as crude as the Mayor is he's intimate with the nature of men and their struggle for achievement. Though I find him personally distasteful, I am fortunate that the Mayor is on my team. I trust he's convinced you that you must exert your efforts in our direction.

CRAMER: It appears I must.

DANKER: Fine. We have harmony.

CRAMER: If forced harmony can yield favorable results.

DANKER: Force has yielded some of the world's finest works, Mister Cramer.

CRAMER: Force has yielded a boycott, Reverend.

(Enter stage right center, JUDGE CARTER--an astute judge dressed in judge's garb.)

DANKER: Ah, Judge Carter--a gentleman because of his fine education and moral plight can appreciate the intellectual and ethical intricacies surfaced by this bus boycott.

JUDGE CARTER: Good afternoon, Reverend, Mayor . . and you're from the bus company. Mister Cramer? 
CRAMER: Yes, Jack Cramer.

(CRAMER stands up and extends his hand. CARTER takes the hand and shakes it.)

JUDGE CARTER: You look restless, son. You haven't let those two rabble rousers bluff you? At this meeting you speak what's on your mind. You hear? It's your legal and moral obligation.

MAYOR GAYLE: It's his obligation to do what's best to keep them buses runnin'.

JUDGE CARTER: (to Cramer) Truth is your obligation.

DANKER: Truth? Which brand of truth, Judge? The legal brand?

JUDGE CARTER: I'm paid to interpret the law, therefore, the decisions I make are based on laws. The moralobligations of the content of those laws rest on the executive--not the judicial branch.

DANKER: Of course. In fact, your honor, we have all been sent here as representatives. You, Judge, as you say, represent the interpretation of the law. Our Mayor represents his southern white constituency. Mister Cramer represents the interests of the bus company. And I represent the church. Our moral obligation is to adequately reflect that which we represent.

JUDGE CARTER: Then I trust that you, Reverend, will adequately reflect Jesus Christ.

MAYOR GAYIE: Look here. This isn't Sunday school. Isn't much time. Judge, you gotta help us before this city explodes. We have to deal with them Nigres the way they have been dealin' with us--tough.

DANKER: A Christian solution?

MAYOR GAYLE: It isn't Christian to boycott buses. That's your Bible talk. We gotta quit pussy-footin' around.

DAINKER: The Mayor's way of saying do unto others as you would have them do unto you. 
MAYOR GAYLE: Listen Reverend, I ain't in the cheek turning business. And I don't plan to let Montgomery get strung up
on no colored man's cross.

(Enter left stage center, MARTIN LUTHER KING. He is followed by STELLA--a poor black woman and by MISTER WALKER--a blind 


\section{$\mathrm{ACT} I$}

\section{SCENE 6}

The lights fade out on the committee and cut on to JAIMES EARL RAY (twenty now). RAY stands in the downstage left apron in uniform at attention holding his wooden rifle which is now completely carved.1 A SERGEANT appears standing in uniform in the aisle.

SERGEANT: It's been my pleasure being your basic training Sergeant these past eight weeks. You have met hell. And you have survived. As a result you are now physically and emotionally excellent fighting men. You are fit to serve your country. You've earned the title soldier. Soldier, who is the cornerstone of our country?!

RAY: (yells) The American fighting man!, Sergeant.

SERGEANT: Two months ago you were ignorant--didn't know how to handle your rifle. But for the past eight weeks you've been one with your weapon. You've cared for her. You've worked her. You've slept with her. Your rifle has been your constant companion. Now, today, you are skilled fighting men . - members of the strongest, best trained military force in the world. Soon you may be in combat. Soldier, who is your most reliable friend?

RAY: (yells) My rifle, Sergeant!:

SERGEANT: And what's the function of your rifle!?

RAY: (yells) To kill!

SERGEANT: I can't hear you!!

RAY: (louder) To kill!! 


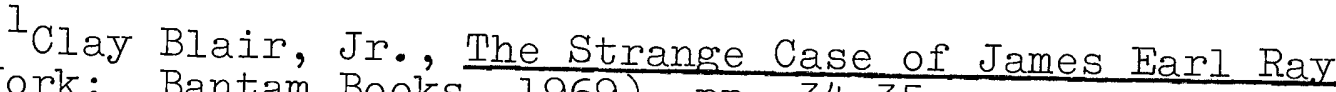

(New York: Bantam Books, 1969), pp. 34-35.

After basic training at Camp Crowder, Missouri, Ray was shipped off for duty in Europe. . .

James Earl Ray was selected for the military police and assigned to the 382nd MP Battalion... . 


\section{ACT I}

\section{SCENE ?}

Lights cut out on RAY and cut on MARTIN IUTHER KING, speaking before the committee. Exit RAY, downstage left.

MARTIN: Gentlemen, it is necessary to put this boycott into its proper perspective. Let me make it absolutely clear that the arrest of Missus Parks is not the cause of this protest. Our action is the culmination of a series of injustices and indignities that have existed over the years. I've brought with me some individuals to testify of the injustice and indignity Negro people have suffered. 1 They have the right to be heard.

JUDGE CARTER: Very well. Introduce your first guest, Doctor King.

MARTIN: Missus Brooks, do you still feel up to telling about your husband?

MISSUS BROOKS: Yes, Reverend. (She stands up.) Someone shoulda told em earlier, when George died. But, I'll tell em now. Don't know that it's gonna do no good. Otta be told though just thah same.

JUDGE CARTER: Please proceed, Missus Brooks.

MISSUS BROOKS: Yes suh. My husband, George and I, we'd been waitin' fer thah bus. It was drizzlin'. I had ìah umbrella. George, he wasn't even wearin' his hat. So when thah bus come George clumb right on. He dropped his dime in the meter and started movin' down thah aisle. But the bus driver he say, "Boy, you know you don't get on my bus from the front. Now get off and board from the back." George stopped. An' he stood there just peerin' down de aisle. I didn't know what had come over him. Colored folks started fidgetin" in their seats. Then George spoke. His voice was clear and calm like it was comin' outa thah damp sky, George he said, "Ah'll walk if you give me back my dime." I wanted to ask George what he thought he was doin'. Wanted to shake him. But I knew I couldn't. Woulda' just made him angry. Lord knows I didn't want to do that. There was the two of them, big as life bickerin' back and forth. 
I Martin Luther King, Jr., Stride Toward Freedom (New York: Harper and Row, 1958), p. 110.

I opened by stating briefly why we found it necessary to "boycott" the buses. I made it clear that the arrest of Mrs. Parks was not the cause of the protest, but merely the precipitating factor. "Our action," I said, "is the culmination of a series of injustices and indignities that have existed over the years." I went on to cite many instances of discourtesy on the part of the bus drivers, and numerous occasions when Negro passengers had had to stand over empty seats. 
What driver wasn't gonna give George back his dime. An' George wasn't gonna leave without it. Then thah driver jumps up an' calls at a policeman. "Hey officer, we got a hot Nigre on our hands." Ah was pleadin' with George, "Forget it George. Forget it." George was lookin' stern at me. Next thing I knew thah policeman was hittin' George with ah club. The old mammies in the back started moanin'. Thah pistol cracked. Thah mammies went quiet. An' George lay there bleedin' at thah stomach. I was cryin', "George, George." They dragged George off thah bus. All thah while I was cradlin' his head. Ah remember ah colored woman whisperin' that thah ambulance was comin'. But ah knew it was the slow ambulance--thah colored man's ambulance. George died. No one said much about it. Someone shoulda. 2 JUDGE CARTER: Is that all, Missus Brooks?

(NISSUS BROOKS is still shaking her head as she sits down.)

MISSUS BROOKS: Shoulda been in thah paper. JUDGE CARTER: Proceed, Reverend King.

MARTIN: I call Henry Walker as a witness. Mister Walker has been blind since the age of nine.

(MR. WAIKER stands carefully, but proudly.)

MARTIN: Go ahead, Mister Walker.

NR. WALKER: Yes suh, it happened on ah Monday mornin'. I know because I was listenin' to thah feet steppin' on thah sidewalk. Monday mornin' people shuffle by a little faster. And they chatter more lively than on Thursday or Friday. It was typical Monday mornin' shufflin'. That Monday started out ordinary. I heard the bus pull up--right on time too. Ah listened to the air brakes. Then I heard the door open. Ah felt the people brush by. Ah heard each of them step three times. A kind hand took my arm, and I stepped forward. My cane felt the step. As I placed my foot, I felt the hand release my arm. I gained a second step. It was routine. Yet, at that moment, as I stood on the second step, a strange feeling came over me. I felt leary. My cane felt, then refelt the third step. There was nothin' on it. So I stepped high. My toe no more than touched the third step than I heard the door. I jerked my foot back. It was too late. 
2 Ibid., pp. 147-148.

Perhaps the most touching testimony was that of Mrs. Stella Brooks. Her husband had climbed on a bus. After paying his fare he was ordered by the driver to get off and reboard by the back door. He looked through the crowded bus and seeing that there was no room in back he said that he would get off and walk if the driver would return his dime. The driver refused; an argument ensued; and the driver called the police. The policeman arrived, abusing Brooks, who still refused to leave the bus unless his dime was returned. The policeman shot him. It happened so suddenly that everybody was dazed. Brooks died of his wounds. 
The door caught me at the ankle. The kind hand yelled. I heard the motor wind. Then the curb slapped my back. The pavement began tearing at my skin. I could hear my wife screaming at the driver. But the street kept scraping. 3 As I struggled to free my foot, I was praying: "Iord I don't wanta die. Save me Lord," A figure flashed into my head. I swear to God it was Moses with his white beard. He was dark.

DANKER: (stands) Moses was not black! JUDGE CARTER: Sit down, Reverend.

(DANKER sits.)

MR. WALKER: Moses was walkin' in the hot sand... stinkin' of sweat. I crawled to him clutchin' at his robe. He stopped and looked down into my soul. His eyes! Weary eyes filled with love fer his chillen'. His eyes smiled. An' the street stopped. Praise de Lord, this ol' body is still livin' today.

(MISTER WALKER slowly and carefully takes his seat.)

MARTIN: If so desired I could bring you a multitude of Negroes each who would reveal his personal experience of indignity and injustice. 4 But today you have heard of a Negro citizen who was murdered for the price of a bus ticket. Today you have heard from a blind man who was trapped at the ankle in the door of a city bus and who might have been dragged to death. No doubt can remain. The present attitude towards Negro passengers is morally intolerable. It is only natural that the Christian passengers have chosen to walk rather than to continue to support a transportation system which deals so injustly with its colored patrons.

DANKER: (stands) Your honor. I object...

JUDGE CARTER: Over-ruled.

DANKER: But . .

JUDGE CARTER: Sit down, Reverend. You'll have your say.

(The REVEREND DANKER sits down.) 
${ }^{3}$ King, Stride Toward Freedom, p. 148.

Mrs. Martha Walker testified about the day when she was leading her blind husband from the bus. She had stepped down and as her husband was following the driver slammed the door and began to drive off. Walker's leg was caught. Although Mrs. Walker called out, the driver failed to stop, and her husband was dragged some distance before he could free himself. She reported the incident, but the bus company did nothing about it.

$$
{ }^{4} \text { Ibia., p. } 147 .
$$

In all, twenty-eight witnesses were brought to the stand by the defense. [Each revealed an experience in Montgomery of indignity related to bus service in Montgomery.] 
JUDGE CARTER: Continue, Reverend King.

MARTIN: Our requests are not unreasonable. We request courtesy from the drivers. Courtesy is the least that any business can grant its patrons. We request that the bus company hire Negro bus drivers to service predominately Negro routes. The bus company admits that seventy-five percent of its patrons are colored. Since Negroes have poured so much money into the pocketbook of the bus company, it is only fair that some of it be returned to the colored citizens in the form of jobs. Furthermore it would be good business for the bus company to seek employees from the ranks of its largest patronage. Finally we request firstcome, first-served seating with Negroes loading from the back and whites loading from the front. Such seating is not unprecedented. Southern cities such as Nashville, Atlanta, and even Mobile, Alabama follow this pattern. And each of them adheres as rigorously to a pattern of segregation as does Montgomery. Surely you can see that our requests are not unreasonable--courtesy from the driver, jobs as bus arivers for some Negroes, and the right to sit in an unoccupied seat without having to give it up to another passenger because the color of his skin is considered superior to the color of ours. There are those here who criticize us for boycotting the buses. Yet we have protested for our right in a non-violent manner with dignity and restraint. It is not our aim to put the bus company out of business. Our aim is to achieve justice for Negroes as well as whites. 5

\section{(MARTIN sits down.)}

JUDGE CARTER: The Reverend Doctor King has stated his position. This gathering will now hear Mister Cramer who represents the bus company.

CRAMER: Reverend King says it is not his aim to put: our company out of business. Yet that is exactly what he is doing. 6 Our bus company has already lost a great deal of money. 6 Doctor King says that he seeks justice. But what manner of justice is the Reverend King seeking? Justice within the Law? No. He can produce no Montgomery law that supports his uncustomary demand that Negroes and Whites have equal access to bus seats. It's customary here that Negro passengers surrender their seats to white passengers. Segregation is not only the custom, but the law in 
${ }^{5}$ Ibia., pp. 110-111.

- I set forth the three requests and proceeded to explain each proposal in detail. I made it clear, for instance, that our request for a firstcome, first-served seating arrangement, with Negroes loading from the back and whites from the front, was not something totally new for the South; other Southern cities--such as Nashville, Atlanta, and even Mobile, Alabama--followed this pattern and each of them adhered as rigorously to a pattern of segregation as did Montgomery. As far as the request for a guarantee of courtesy from the drivers was concerned, "this is the least that any business can grant to its patrons," I said. And finally I pointed out that since the Negroes poured so much money into the pocketbook of the bus company, it was only fair for some of it to be returned to them in the form of jobs as operators on predominately Negro routes. "The bus company admits," I reminded them, "that seventy-five percent of its patrons are colored; and it seems to me that it would be good business sense for the company to seek employees from the ranks of its largest patronage." I closed my remarks by assuring the commissioners that we planned to conduct the protest on the highest level of dignity and restraint, and I avowed that our aim was not to put the bus company out of business, but to achieve justice for ourselves as well as for the white man.

6 David L. Lewis, King: A Critical Biography (New York: Praeger Pub., 1970), pp. 66-67.

By the third month of the boycott, the restricted travel of blacks had resulted in the loss to local merchants of more than \$l million. The loss of revenue caused the business community to mobilize.

7 King, Stride Toward Freedom, pp. 1ll-1l2.

Then the commissioners and the attorney for the bus company began raising questions. They challenged the legality of the seating arrangement that we were proposing. They contended that the Negroes were demanding something that would violate the law

It soon became clear that Crenshaw, the attorney for the bus company, was our most stubborn opponent. Doggedly he sought to convince the group that there was no way to grant the suggested seating proposal without violating the city ordinance. . . 
- Parks had hardly closed his mouth before Crenshaw rejoined,". . I don't see how we can do it within the law. If it were legal I would be the first to go along with it; but it just isn't legal. The only way that it can be done is to change your segregation laws."

\section{${ }^{8}$ Ibid., p. 117.}

"We have been talking a great deal this morning about customs," I concluded. "It has been affirmed that any change in present conditions would mean going against the 'cherished customs' of our community . . . " 
MARTIN: A first-come, first-served seating arrangement can exist entirely within the segregation law. As I stated, it is in many Southern cities.9

CRAMER: What you propose Doctor King, is integration not segregation. In Montgomery integration is illegal. It's as simple as that. Our company is a guest of this city. Being a respectable guest we can only abide by the will of our host. The will of Montgomery is segregation as reflected historically, legally, and by the custom of this city's
people.10,11

(MARTIN rises quickly.)

MARTIN: Mister Cramer is not being fair in his assertions. He has made a statement that is completely biased. In spite of the fact that he was asked to come to Montgomery by the M-I-A, and in spite of the fact that he has been in town three days, he has not done the Negro community the simple courtesy of coming to hear our grievances. The least that all of us can do in our deliberations is to be fair and honest.12

MR. WALKER: Amen. Amen brother. ${ }^{13}$

(JUDGE CARTER bangs the gavel once.)

DANKER: Reverend King you're over anxious to speak about public transportation. Your domain is salvation.14

JUDGE CARTER: Order.

(MARTIN remains standing.)

MARTIN: Salvation and public transportation are more closely related than you choose to believe, Reverend Danker.

(JUDGE CARTER bangs gavel.)

JUDGE CARTER: Order! Order! Any further such outbursts gentlemen and I will disband this meeting! Mister Cramer, you have the floor. 


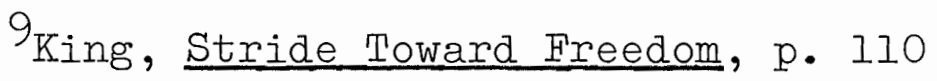

I made it clear, for instance, that our request for a first-come, first-served seating arrangement, with Negroes loading from the back and whites from the front, was not something totally new for the South; other Southern cities--such as Nashville, Atlanta, and even Mobile, Alabama--followed this pattern . . .

$$
10_{\text {Ibid., }} \text { pp. III-II2. }
$$

Then the commissioners and the attorney for the bus company began raising questions. They challenged the legality of the seating arrangement that we were proposing. They contended that the Negroes were demanding something that would violate the law. . .

It soon became clear that Crenshaw, the attorney for the bus company, was our most stubborn opponent. Doggedly he sought to convince the group that there was no way to grant the suggested seating proposal without violating the city ordinance. . .

- Parks had hardly closed his mouth before Crenshaw rejoined,". I don't see how we can do it within the law. If it were legal I would be the first to go along with it; but it just isn't legal. The only way that it can be done is to change your segregation laws."

\section{${ }^{11}$ Ibid., p. 117 .}

"We have been talking a great deal this morning about customs," I concluded. "It has been affirmed that any change in present conditions would mean going against the "cherished customs' of our community . . ."

$$
12 \text { Ibid., p. } 116 .
$$

Then unable to restrain myself any longer I jumped to my feet and gave voice to my resentment: "Mr. Totten has not been fair in his assertions. He has made a statement that is completely biased. In spite of the fact that he was asked to come to Montgomery by the MIA, he has not done the Negro community the simple courtesy of hearing their grievances. The least that all of us can do in our deliberations is to be honest and fair." A chorus of amens could be heard from the Negro delegation. Neither the mayor nor C. K. Totten replied, but the latter shifter uncomfortably in his seat. 
13 Ibid.

14

Lewis, King: A Critical Biography, p. 65.

Martin reproached [C. K.] Totten [the northern emissary] with some acerbity, for his deliberate failure to confer with the black leadership. In turn, he was gravely and eloquently reproved by for dereliction of ministerial duties. Salvation, not public transportation, he said, was the province of the pastor. 
CRAMER: I have nothing further to say your honor. I've stated the position of my company. I yield to the Reverend King.

MARTIN: Mister Cramer has been talking a great deal this morning about customs. He has affirmed that any change in the present conditions would mean going against the cherished customs of our community. But if the customs are wrong we have every reason in the world to change them. The decision which we must make now is whether we will give our allegiance to outmoded and unjust customs or the ethical demands of the universe. As Christians we owe our ultimate allegiance to God and His will, rather than to man and his folkways.15

(MARTIN sits; REVEREND DANKER stands.)

REVEREND DANKER: Your honor, it seems the discussion has at last arrived at God. And since I have come here for the sole purpose of speaking about the true nature of Christianity, I think it is fitting that I be heard at this time.

JUDGE CARTER: Proceed, Reverend Danker.

REVEREND DANKER: God's book--our Bible--is a bounty. Not many of us understand the nature of God's book. Our Bible is a spiritual book. The disciple John wrote "It is the spirit that gives life, the flesh is of no avail." If the Bible were of the flesh it would be of no avail. It would be temporal--nothing. But fortunately the Bible yields a wealth of teaching which is of the spirit. For it reflects the life of Jesus. I know Jesus. I have had an experience with Jesus. I know that Jesus gave up his job as a carpenter. And I know that he left his immediate family. Why? So that he could go into the vast wilderness afoot and teach the word of God. Jesus gave up the world of flesh. Jesus was spiritual, not worldly. Jesus lived a spiritual life. He sought the spiritual element of man. He conquered through the spirit of love. Boycott is not a spiritual solution. It is temporary--like wind on high grass. Because of this boycott Montgomery people may bend a certain way. But when you release the boycott the citizens of Montgomery will straighten right back up. The nature of boycott is coercion. And coercion cannot change permanently the nature of a man. Jesus didn't coerce. Jesus loved. Apply love and people will bend by themselves permanently. Jesus Christ was murdered while trying to teach us how to love. And so the clergy must bear the burden of the work of Jesus Christ. The duty of the clergy is to lead man to God, not to bring about 
${ }^{15}$ King, Stride Toward Freedom, p. 117.

"We have been talking a great deal this morning about customs," I concluded. "It has been affirmed that any change in present conditions would mean going against the 'cherished customs' of our community. But if the customs are wrong we have every reason in the world to change them. The decision which we must make now is whether we will give our allegiance to outmoded and unjust customs or to the ethical demands of the universe. As Christians we owe our ultimate allegiance to God and His will, rather than to man and his folkways." 
confusion by getting tangled up into transitory social problems. There are two environments--the worldly environment of man and the spiritual environment of God. I implore the Negro ministers to bring this boycott to a close and lead your people instead to a glorious experience of the Christian Faith. 16

(MARTIN stands as REVEREND DANKER sits.)

REVEREND KING: We, too, know the Jesus the minister refers to. We have had an experience with him, and we believe firmly in the revelation of Jesus Christ. I can see no conflict between our devotion to Jesus Christ and our present action. In fact I see a necessary relationship. If one is truly devoted to the religion of Jesus he will seek to rid the earth of social evils. The gospel is social as well as personal. We are only doing in a minor way what Gandhi did in India; and certainly no one referred to him as an unrepentant sinner; he is considered by many as a saint. 17

MAYOR GAYIE: May I be heard!

JUDGE CARTER: Are you finished, Doctor King?

MARTIN: For now. Let Mayor Gayle be heard.

JUDGE CARTER: Proceed, Mayor.

MAYOR GAYLE: Thank yah Judge. Ah been sittin' listenin' respectfully now for near an hour. I heard you all talkin. about law, an Jesus, an Gandhi. But I haven't heard no one talkin' about the white citizens of this community. So I'm tellin' it now clear. I'm speakin' for the white people of Montgomery. The white folk aren't going to tear apart the social fabric of this community by lettin' Negroes sit in the white seats of them city buses.18 That's all... That's all. Now you keep picken' at 'em white folk... you keep boycottin' them buses, and hell is gonna break loose in Montgomery.

(Black out. Exit cast, stage right. Enter CORA and MARY LUCY, stage left. Sound of heavy thump, center left stage.) 
16 Ibid., pp. 116-117.

I remember especially the words of Dr. Frazier--one of the most outspoken segregationists in the Methodist Church. . . He talked persuasively about the frailties and weaknesses of human nature. He made it clear that he felt the Negroes were wrong in boycotting the buses; and the even greater wrong, he contended, lay in the fact that the protest was being led by ministers of the gospel. The job of the minister, he averred, is to lead the souls of men to God, not to bring about confusion by getting tangled up in transitory social problems. . . He urged the Negro ministers to leave the meeting determined to bring this boycott to a close and lead their people instead "to a glorious experience of the Christian faith."

17 Ibid., p. 117 .

"We too know the Jesus that the minister just referred to," I said. "We have had an experience with him, and we believe firmly in the revelation of God in Jesus Christ. I can see no conflict between our devotion to Jesus Christ and our present action. In fact I see a necessary relationship. If one is truly devoted to the religion of Jesus he will seek to rid the earth of social evils. The gospel is social as well as personal. We are only doing in a minor way what Gandhi did in India; and certainly no one referred to him as an unrepentant sinner; he is considered by many as a saint ..."

${ }^{18}$ Lerone Bennett, Martin Iuther King, Jr.: A Profile, ed. C. Eric Lincoln (New York: Hill and Wang, 1970).

The white people are firm in their convictions that they do not care whether the Negroes ever ride a city bus again if it means that the social fabric of our community is destroyed so that Negroes will start riding buses again. 


\section{ACT I}

SCENE 8

Lights fade up dimly on the King living room. CORA is holding YOLANDA ( 9 weeks old) in her arms. With her is a lady church friend--MARY LUCY.

CORA: Sounds like something's hit the porch.

(CORA leading, they start moving backwards when: downstage explosion--flash. MARY LUCY screams. Sound of doorbell.) I

CORA: (whisper) They're coming in after $u^{2}$. . (pause) . . Who is it?

BIACK MAN: (voice offstage at door) Anybody hurt? 3

CORA: We're all right.

(Fade in gathering crowds, sounds of angry concerned blacks on the porch side of the street. Slides on screen of angry black crowd outside. ${ }^{4}$ Telephone rings. CORA answers it.)

CORA: Hello.

WOMAN'S VOICE: (over telephone) I did it. And I'm sorry I didn't kill all you bastards.5

(Fade down then out lights on King living room and then CORA. Begin MARTIN LUTHER KING'S speech taped. The real speech he gave to that angry crowd that night--edited. Crowd sounds grow angrier. A grainy slide of MARTIN LUTHER KING appears on screen. As MARTIN begins speaking fade under crowd sounds. Intersperse slides of angry crowd. Meanwhile, exit MARY IUCY and enter DADDY KING, kitchen exit and entrance.) 
${ }^{1}$ Coretta Scott King, My Life With Martin Iuther King, Jr. (New York: Holt, Rinehart and Winston, 1969), p. 127 .

- Monday, January 30, 1956. At about nine-thirty in the evening . . . I heard a heavy thump on the concrete porch outside. . . I said, "It sounds as if someone has hit the house. We'd better move to the back. . . there was a thunderous blast. Then smoke and the sound of breaking glass. Mary Lucy grabbed me and started screaming. Her screaming frightened me, and I was shaken by the impact of the noise. . . the doorbell started ringing. My first thought was that it was the person who had thrown the bomb. . . I shouted, "Who is it?" and a voice said, "Is anybody hurt?"

${ }^{2}$ Lerone Bennett, What Manner of Man (Chicago: Johnson Pub., 1968), pp. 69-70.

"My first thought," Coretta King said, "was that they are coming in now. . . Finally, a voice said: 'Is anybody hurt?' I knew then they were friendly callers. - . the telephone started ringing. Somebody answered and a woman said: 'Yes, I did it; And I'm just sorry I didn't kill all you bastards." "

${ }^{3}$ Coretta Scott King, p. 127. 4 Ibid., p. 128.

Then Martin rushed home. By the time he got there a big angry crowd was around the house. The police were nervously holding the people back.

5 Bennett, pp. 69-70. 
On audio tape:

MARTIN: My wife and my baby are all right. I want you to go home and put down your weapons. We cannot solve this problem through retaliatory violence. We must meet violence with non-violence. Remember the words of Jesus: "He who lives by the sword will perish by the sword." We must love our white brothers, no matter what they do to us. We must make them know that we love them. Jesus still cries across the centuries. "Love your enemies." This is what we live by. We must meet hate with love. Remember, if I am stopped, this movement will not stop, because God is with this Movement. Go home with this glowing faith and this radiant assurance.

VOICE SHOUTS IN CROWD: God bless you. 6

(Fade out slide. Fade out crowd noises.) 
${ }^{6}$ Coretta Scott King, pp. 128-129. 
ACT I

SCENE 9

Fade up lights. DADDY KING and CORA sit talking in the living room. The atmosphere is family comfortable. The mood is tense.

CORA: Daddy King, I'm grateful that you're concerned for Martin's safety, but...

DADDY: Not only for Martin's safety, Cora. I'm frightened for your safety and the safety of the baby as well. The family is in danger here in Montgomery. 1

CORA: Don't you think I know that. Each time the telephone rings I have to force myself to answer. I'm afraid a sick mind will be on the other end. I detest obscene calls.

DADDY: It's time to protect your family.

CORA: The threats come daily now.

DADDY: Coretta, I've come here to get you and the family. I want you to come to Atlanta for a few weeks till this thing cools off.

CORA: I want the family to be together.

DADDY: Be together. But not here. Not here where your lives are being threatened.

CORA: Martin can't leave now.

DADDY: I don't understand you, Cora. You're like my own flesh and blood. But I don't understand you.

CORA: Daddy King, listen. Our family has more than others. We have Martin himself each day. Martin has taught us that the spiritual sickness dividing men can be healed with love, Daddy. The proof of love is sacrifice. That's why we're staying. We're proving our love.

DADDY: I hear a brave mother. But does a brave mother have the right to endanger her children? Don't underestimate the power of your enemies in Montgomery. Listen to your Daddy King, daughter. 
${ }^{I_{\text {Coretta }}}$ Scott King, My Life With Martin Luther King,

Jr. (New York: Holt, Rinehart and Winston, 1969), p. 132 .

Daddy King had said as soon as he arrived, "Well, M. L., you just come on back to Atlanta." [Coretta's father said;] "They're after you, Martin. I think you ought to move into the background and let someone else lead for a while, and, Coretta, I've come here to get you and the baby and take you home for a few weeks till this thing cools off." 
CORA: I have, I always will.

DADDY: Do that and you'll ripen to an old age.

CORA: That's your best offer?

DADDY: It's a better offer than you believe. Age has its value--experience. Take myself. I've never been well educated.

CORA: Not academically.

DADDY: No. But I've been well schooled. My schoolhouse has been life. And you know something, daughter, life if lived truthfully is a strict school mammy. I'm an old preacher that's stood up for what's his and his neighbors.

CORA: Am I listening to the history of a brave man?

DADDY: Sometimes good sense is more important than bravery. There was a time in my youth when I too was carelessly brave. I was eleven at the time--just a boy helping my Daddy sharecrop a small cotton field. I remember the hot sun beating on the dust at daybreak as my Daddy and I set out for the boss's workshop. Each time I stepped the warm dust sifted up between my toes. The two of us had finished the hard work of harvest. Yet, that day we walked the two miles quicker than usual. For it was payday--the day we were to receive our fair share of the cotton crop. After what seemed like eternity we arrived and entered the boss's shack. Soon the boss began adding up our share of the cotton crop out loud. I listened carefully. Suddenly he looked up, slapped the big black book shut and grinned broadly at my Daddy. His words rang clear in the still heat. "We're all even," he exclaimed. He meant that our grocery bill for the year had equalled our share of the crop. I looked up at my Daddy. His face reflected no surprise. He looked dazed. My small hand flashed up and tugged his sleeve. Excitedly I whispered, "Papa the boss forgot seven and a half sacks." That was nearly a thousand dollars-a fortune to us. The boss's eyes turned to ice.

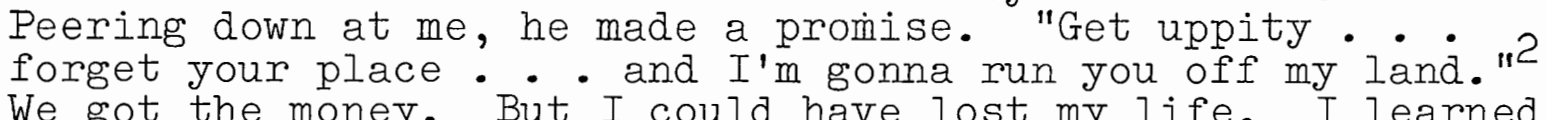
that day. I learned to fear the racist.

CORA: You learned that a man has to stand up for what's his and his neighbors. And you have taught your lesson to Martin. Martin has told me many times what a brave example you were. 
2 Ed Clayton, Martin Luther King: The Peaceful Warrior (New York: Washington Square Press, 1969), pp. 4-7.

When the boss had finished he turned to Martin's father with a grin. "Well, we're all even," he said.

What the boss meant by "even" was that Mr. King's share of his cotton crop would be just enough to pay for the food and other supplies that the King's had bought for credit at the boss' store during the past winter. Young Martin had been quietly observing the boss figuring with an eagle eye.

- . he said to his father, "Papa, the boss forgot to add in over seven and a half sacks of seed--and that amounts to almost a thousand dollars."

- . the boss was not pleased. "Just you remember," he threatened Martin, "I don't stand for no troublemakers. If you get uppity and forget your place, I'm going to run you off my land. Y'hear?" 
DADDY: Alright. Alright! But the truth is I've faced people violent and non-violent, white and black alike. I've seen white cities riled. Have you forgotten so quickly the bombing of your home? White Montgomery is riled. Think of your family. In an instant hate flashed tonight. You and the baby could have been killed.

(DADDY KING places his hand on CORA'S.)

DADDY: Come to Atlanta.

(CORA thinks.)

CORA: I think I'll stay here. 3,4

(Enter MARTIN stage left, worn and somewhat preoccupied. DADDY KING and MARTIN embrace--a hug.)

DADDY: It's good to see you and your family alive...

MARTIN: I'm glad you're here. I tried to telephone to let you know we were all right. (Moves to the window and looks out.) But the mob. . . when I did get to you, mother answered. She said you were on your way.

DADDY: Hearing your voice . . being assured that you and the family are unharmed eased her mind. I'm certain.

MARTIN: Outside . . out there it's silent now. Our street is vacant, noiseless like a mute witness. Our brothers have dispersed for the night. Thank God.

DADDY: I have.

MARTIN: - . as I was speaking I was watching them. And you know what I perceived? I perceived them eyeing me. That instant my shoulders went heavy. For I realized that in my imperfection I was their model. If I appeared weak they would leave me and forsake the non-violent movement on the spot. They stood out there peering into me, lead pipes in hand, anger in their eyes. Balancing on the brink of bloodshed we waited listening for one another's pulse.5 If a riot had erupted our non-violent struggle could have been 
${ }^{3}$ Coretta Scott King, p. 132.

with Martin. ". . "

I answered my father, saying again, "Well, I think I'll stay here. I would not be satisfied if I went home. I want to be here with Martin."

${ }^{4}$ Ibid.

Though I had sounded so brave, I was torn. Martin and I both realized that there was a possibility of something happening to us. The house might be bombed again; the baby and I could be killed the next time.

5 Ibid., p. 129.

The situation outside the house was tense and dangerous. Though the crowd was singing, the people were angry and aroused. I remember hearing "My Country, "Tis of Thee," but you could sense the heat of their anger. Many were armed: even the little boys had broken bottles. A policeman held back one black man who said, "You got your thirty-eight, I got mine. Let's shoot it out."

Later someone said tension was so high that if a white man had accidently tripped over a Negro, it could have triggered the most awful riot in our history. 
ruined, broken. This could well have been the darkest night in the history of Montgomery. 6

DADDY: And in the history of our family.

MARTIN: (pause) How many of them know, really understand?

DADDY: , M. L. we must talk.

MART IN : Hmmmm.

DADDY: Sit down, I want to talk.

(MARTIN moves to the couch and sits. He says:)

MART IN: It was frightening . . terrifying . . like talking to a thousand individual bottles of nitroglycerin.

DADDY: M. I., I want you to come on back to Atlanta . • Pack up, Martin. You and your family come to Atlanta... come to safety.?

MARTIN: (pause) I thought about it. (Pause.) I thought about Yolanda, Cora and myself, about our safety. And then I thought about my daughter's future, and the future of all the black sons and daughters. The truth is clear. I know I must stay. I know the truth.

DADDY: They're out to get you. That's the truth. 8

MARTIN: Wherever I've been I've found prejudice. If I went with you to Atlanta, I would find prejudice there too. When I was a child, you and I found prejudice. And when we found it we faced it together. Now, still I find prejudice and face it. Tonight in Montgomery prejudice erupted. We must consistently meet prejudice with non-violence. Only when Negroes and those sympathetic for Negroes have won this battle, will they have carved confidence. Once we've beat Montgomery--once we've proven ourselves, non-violent supporters will arise and suffer for Negro rights in a thousand Montgomerys.

DADDY: It is better to be a live dog, than a dead lion. 9 MARTIN: I'd be a coward to hide. I couldn't live with myself if I hid while my brothers and sisters were being arrested. I'd rather be in jail ten years than desert my 
$6_{\text {Martin Iuther King, Jr., Stride Toward Freedom }}$ (New York: Harper and Row, 1958), p. 138.

This could well have been the darkest night in Montgomery's history.

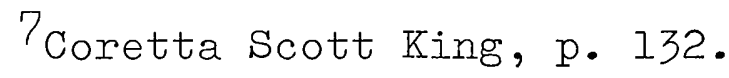

Daddy King had said as soon as he arrived, "Well, M. I., you just come on back to Atlanta."

8 Ibid., p. 134.

Daddy King made a little talk to them. He told them of the threats and the bombings and his belief that the white people were out to get Martin.

${ }^{9}$ Ibid., p. 132 .

When Martin objected, Daddy King said, "It's better to be a live dog than a dead lion." 
people now. I've begun the struggle and I can't turn back. I've reached the point of no return.

(DADDY KING bursts into tears. ${ }^{10}$ Close curtain.) 


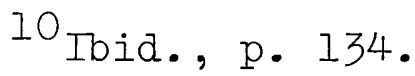

"I must go back to Montgomery. I would be a coward to stay away. I could not live with myself if I stayed here hiding while my brothers and sisters were being arrested in Montgomery. I would rather be in jail ten years than desert my people now. I have begun the struggle, and I can't turn back. I have reached the point of no return." - . The silence was broken as Daddy King burst into tears. 
ACT I

SCENE 10

Lights fade out on living room set. Meanwhile, a spotlight picks up the OLD BLACK WOMAN walking slowly across the downstage apron towards town. A BLACK MAN runs on stage, down stage. He packs some flyers.

BLACK MAN: Long live--the King! We ain't gonna ride the buses no more. I Here. (Hands a flyer to the OLD BLACK WOMAN.) Read it yourself.

(BLACK MAN continues running off stage. The OLD BLACK WOMAN moving slowly, reads:)

OLD BLACK WOMAN: The United States Supreme Court unanimously rules that bus segregation laws in Montgomery, Alabama are unconstitutional.2

(Se stops, turns to the audience, and says:)

OLD BLACK WOMAN: God Almighty has spoke from Washington:3

(Curtain descends just in front of her.) 
${ }^{I}$ Lerone Bennett, What Manner of Man (Chicago: Johnson Pub., 1968), p. 76.

When King was convicted on March 22, he and Coretta emerged from the courtroom, smiling triumphantly. On the court house steps, the young couple was hailed by a large crowd of demonstraters, shouting: "Long Iive the King! We ain't gonna ride the buses no more."

2 Martin Luther King, Jr., Strength to Love (New York: Harper and Row, 1963), p. 50.

-. I read these words: "The United States Supreme Court today unanimously ruled bus segregation unconstitutional in Montgomery, Alabama. . . " Someone shouted from the back of the courtroom, "God Almighty has spoken from Washington." 


\section{ACT II}

SCENE 1

Setting: ghetto flat is dimly lit. RANDEI, a black wiry youth in his late teens, is cleaning inside. At present he is not lit. Enter MARTIN and CORA downstage apron right, moving toward their flat upstage left. MARTIN carries two suitcases.

MARTIN: What do you think?

CORA: About Chicago or her slum?

MARTIN: Her slum. Are you certain you want to go through with this? I have no choice. I must live here. But you

CORA: Can't you understand? Just like you, I have an urge
to serve.1 MARTIN: Don't neglect your first priority.

CORA: The family. I haven't forgotten: We stayed together in Montgomery.

MARTIN: This will be worse than Montgomery. If your welfare or the welfare of the children are seriously threatened here, you must leave.

CORA: (pauses) Yes, of course. You are right. (Pause.) Martin, you know something?

MARTIN: What?

CORA: I can't wait until city hall suddenly discovers that Doctor Martin Iuther King and his family have moved into Chicago's dilapidated tax shelter.

(MARTIN chuckles. They begin moving toward their flat using a more direct course. Apartment lights come up stronger. We percieve RANDEL cleaning the flat.2) 
${ }^{1}$ H. P. Leifermann, "Profession: Concert Singer, Freedom Movement Lecturer, "New York Times Magazine, November 26, 1972 , pp. 52-56.

"He'd say, 'I have no choice, I have to do this but . . .' And I'd say, Can't you understand? You know I have an urge to serve just like you have. I don't know why it is, I can't explain it, but all I know is that it's there."

${ }^{2}$ David I. Lewis, King: A Critical Biography

(New York: Praeger Pub., 1970), p. 315.

On Sunday, January 23, 1966, the nation's news media reported that Martin Luther King had installed himself the day before in a Lawndale slum tenement at 1550 South Hamlin Avenue. When Bernard Lee, in whose name the apartment was leased, had arrived with an associate on Friday to inspect the premises, he found four plasterers, two painters, and two electricians furiously working to transform the apartment so that it would meet the standards of the municipal housing code. 
MARTIN: Twenty-ninth Street. It's about where our flat should be.

CORA: It can't be our flat. I see a figure--a young man inside.

(MARTIN glances at his watch.)

MARTIN: Swing shift's getting home about now. Must be a night worker.

CORA: The address. I can make it out. Martin! It's our flat!:

(RANDEL stops working, looks toward MARTIN and CORA who are approaching. Then he moves to the imaginary door.)

RANDEL: Doctor and Missus King, Chicago welcomes you.

(RANDEL gestures in a sweeping motion with his arm which says: enter distinguished ones. They enter.)

RANDEL: My name's Randel. . Randel Jacobs. We're neighbors. I live with my mother in the flat next door--at least in morning and evenings. The rest of the time I'm at college or work. Oh, ah I suppose you're wondering why I'm in your home at such an unhospitable hour. Our landlord George Baird who my mother house nigger's for hired me to clean up.

CORA: Your mother's a cleaning woman?

RANDEL: Exactly.

MARTIN: Does Mister Baird prepare his rentals this thoroughly for all his new tenants?

RANDEL: Of course not. This, Reverend King, is an exclusive cleanup--Chicago's gesture of goodwill for an influential civil rights leader. You should have arrived earlier. You'd have seen plasterers, painters, and electricians on the job.3 Baird aims to please.

MARTIN: Could you carry a message to Mister Baird from me? 
3 Ibid. 
RANDEL: Sure.

MARTIN: Tell Mister Baird that I don't cherish any special privileges when I see thousands and thousands of my brothers and sisters subjected to the same degrading conditions. 4

RANDEL: A noble message, Reverend King. Tell me, how do you plan to rehabilitate this degrading hell named Lawndale?

MARTIN: Through non-violent confrontation.

RANDEL: Lawndale is a complicated jungle. Non-violent confrontation won't be easy here. Our enemies are powerful. Exploitive merchants line our streets and wield economic power.5 They receive the black workers' dollars and render the black workman jobless.

MARTIN: We are already consulting individually with Chicago's businessmen. We're seeking jobs for Negroes. We call this plan Operation Breadbasket.6 It's already yielding some jobs.

RANDEL: How can it work? You ask for a job and whitey refuses. What then?

CORA: We hit them where it hurts the most--the pocketbook.?

MARTIN: We will boycott the products of any company which refuses to hire Negroes. When Chicago Negroes and white sympathizers unite and non-violently wield their buying power, ghetto people will have jobs.

CORA: In Montgomery we boycotted..

RANDEL: . . in Montgomery? The small time political leaders in Montgomery are not the sophisticated power structure of Chicago. Enemy politicians who stalk the streets of Lawndale are not only masters of abusing power, but excel in hiding behind a cover of ambiguity. You must define our political enemies before you can confront them. They won't define themselves. Read--where is your confrontation in Chicago?

(RANDEL thrusts the newspaper at MARTIN and points at an article.)

MARTIN: (reads) Headlines--"Plan New Drive on Slumlords." The article states the fifty housing inspectors will be 
${ }^{4}$ William Robert Miller, Martin Iuther King, Jr.

(New York: Weybright and Talley, 1968), p. 236.

I don't cherish any special privileges when I see thousands and thousands of my brothers and sisters subjected to the same degrading conditions.

${ }^{5}$ Louis Lomax, Martin Luther King, Jr.: A Profile, ed. C. Eric Lincoln (New York: Hill and Wang, 1970), p. 170.

In Chicago, Martin Luther King found himself fighting the system, that powerful combination of exploitative merchants, corrupt politicians, and amoral gangsters. These were the men who controlled ghetto life. They still do . . •

$6_{\text {Miller, p. } 257 .}$

The program [Operation Breadbasket] . . involved a team of ministers requesting certain basic facts from business enterprises operating in their community. . . These data were studied; then the ministers would return with proposals for hiring and upgrading Negroes in proportion to their population in the city. If negotiations broke down, the ministers organized boycotts and picket lines. . . King told the conference, ". . we are seeking to hit the system where it hurts--in the pocketbook."

7 Tbid. 
added to the city's force. It warns that landlords guilty of housing code violations will be vigorously prosecuted.8

RANDEL: Read farther down. You're mentioned farther down.

MARTIN: The mayor asks the Reverend Doctor Martin Luther King to help projects already underway. 9

CORA: Already underway!

RANDEL: City hall will order a few landlords to clean up. They'll get tough here and there to keep up their image until Martin Luther King leaves. Chicago power will disperse your platform. When it comes to non-violently confronting the political enemies of Lawndale, I wish you well. But I'll put my bread on Chicago power over non-violence.

(CORA reaches out and takes MARTIN'S hand.)

MARTIN: You'll lose. Non-violence holds its own power. RANDEL: You'll have to prove it.

MARTIN: We'll prove it. I see that we must educate and inspire our ghetto brothers and sisters.

RANDEL: Don't say a word. Not a syllable. Just show me. Show me the power of non-violence. You're "De Lawd." 
${ }^{8}$ Lewis, King: A Critical Biography, p. 316.

On February 10, the huge Chicago Tribune headines pushed much of the usual volume of news off the front page to announce, "Plan New Drive on Slumlords." The paper stated that fifty housing inspectors were geing added to the city's force and that landlords guilty of housing-code violations were to be vigorously prosecuted.

9 Thomas B. Morgan, "Requiem or Revival," Iook, June 14, 1966, p. 72 .

Rather than fight Dr. King, Mayor Richard J. Daley, a liberal Democrat, blandly asks him to help improve projects already underway. As a result, the fate of the movement is in serious doubt, while the issue of Negro inequality ticks on. 
SCENE 2

Curtain closes. Light fades up on LUCIJLE sitting on the downstage right apron. LUCILLE sits flat on the floor, her legs sprawled unladylike. She's aged by booze. Her hair is stringy and filthy. Her clothes are rags.I Beside her is a bottle of wine. She's unwrapping a bread crust. Suddenly she shakes the bread crust and slaps her hand on the stage.

LUCILLE: Damn cockroaches:

(As JAMES EARL RAY sneaks through the shadows downstage left towards her, LUCIIIE takes a bite of bread. JAMES carries his wooden rifle now completely carved and stained. A distant siren fades in. JAMES freezes. The siren fades out.)

RAY: Mother, that you mother?

LUCILLE: Huh, someone there? Someone out there?

\section{(JAMES EARL RAY approaches her.)}

LUCILLE: It's you, Jimmy. Ain't it. I hear the police is after you.

RAY: Ain't seen my brother or sisters for two years. You're alone now. Where's the kids?

LUCILLE: State come and took $\mathrm{em}_{2}$.. ' 'cept for the ones that ran away to your grandma's.?

RAY: And Dad?

LUCIIIE: Left us. ${ }^{3}$ He weren't no good anyhow. Used tah spend all his time in the pool hall. Should ah been workin'. We had twelve kids tah feed.

RAY: Was hard times. Weren't no work or money for him . • 'cept when old Gus gave him some used oil to sell. 4 
${ }^{1}$ Clay Blair, Jr., The Strange Case of James Earl Ray (New York: Bantam Books, 1969), pp. 36-37.

James Earl Ray arrived home from the Army in January, 1949. What he found in the dirty house at 214 Spring Street was less than encouraging. His father was not working. There was no money, little food. The indefatigable Lucille had given birth to two more children. . . Now fat and disheveled, Lucille was drinking steadily--mostly wine . • .

$$
2 \text { Ibid., pp. } 44-45 \text {. }
$$

Iucille was drunk much of the time. . . In about March of 1952, James Gerald abandoned his family. • • Melba, Carol Jean, Buzzy, Susan and Max were declared wards of the court. Carol Jean escaped, going first to great Aunt Sadie Fitzsimmons in Alton, and later to live with her father in st. Louis. Buzzy and Susan and Max fell into the care of the Catholic Charities and were sent to the Catholic Children's Home in Alton.

$$
\begin{aligned}
& 3 \text { Ibid. } \\
& { }^{4} \text { Ibid., p. } 26 .
\end{aligned}
$$

The owner of the garage recalls: "Old Gerry Raines was always coming by in the morning in his truck saying: 'You got any used motor oil today?' - How Gerry Raines managed to eke out a living in those years remains a minor mystery. . . But among the poor in Ewing, a lack of visible means of support was not a noteworthy failing. 
LUCILLE: He didn't bust his back lookin' fer work neither. Otta been, me in rags. No satin aress like he promised me. And my home. I took the wood off the walls to feed the fire on cold winter nights.5 Do you remember, Jimmy?

RAY: I remember.

LUCILLE: What happened, Jimmy? How comenone ah my kids is worth nothin'? Always thought you'd make it, Jimmy. There was a time you held a steady job. 6

RAY: I got money.

(JAMES EARI RAY pulls out a bundle of bills.)

LUCILLE: Land sakes, child. Ah never seen so much money all together. You din't steal this?

RAY: I got an employer . . powerful employer.?

LUCILLE: What you doin' tah earn this kind of money?

RAY: Can't say. But it's somethin' that'll make me important.. real important.

LUCILLE: Life's been unkind tah me, son. Ain't had nothin' fit tah eat lately.

RAY: I gotta keep my money tah stay hid. They catch me they'll put me back in prison. (Pause, as RAY looks at his mother.) Ah can give yah some.

LUCILLE: Half?

(JAMES EARL RAY makes two even piles of money.)

LUCILLE: You're a good boy, Jimmy. You always was.

(JAMES gives LUCILLE one of the piles of money and stuffs the other in his pocket. Then he disappears into the darkness, stage left and exits.)

LUCILLE: Son. (No answer.) Ah'm sorry.

(LUCILLE picks up her wine bottle and exits stage right.) 


\section{${ }^{5}$ Tbid., p. 32.}

To get firewood, members of the family ripped up the floors and tore down the walls of the house.

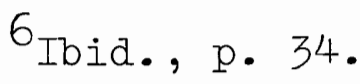

Ray worked diligently for two years, 1944 to 1945. Then came a shock. Business at International shoe fell off sharply, perhaps because of a cutback in defense orders. Jimmy Ray was laid off. It was not due to incompetence or lack of ambition or willingness to work.

\section{Ibid., pp. 16-18.}

In Atlanta, the two people closest to Dr. King, his wife and his father, summed up the attitude of the vast non-violent black community. Said Coretta King: "This plea of guilty cannot be allowed to close the case or to end the search for the many fingers which helped pull the trigger."

Said the Reverend Martin Luther King, Sr.: "No one man took my son's life." Similar sentiments were voiced by Dr. Ralph Abernathy, who succeeded King, and by NAACP leader Roy Wilkins.

There were dozens of questions left unanswered by the swift proceedings in Memphis. Among them:

- . 3. If there was no conspiracy, where did Ray get the money--estimated at $\$ 12$, 000 or more--to live on the year between his escape from the penitentiary and the murder? 4. How was this bungling hillbilly able to dramatically change his personality and style of living to that of the suave, dapper, fictional Eric Starvo Galt? . . 6. Who helped Ray with mysterious visits in Winnetka, telephone calls in Toronto and England? 7. Who is the "friend" who gave Ray a .38-caliber pistol? . . 9. Who helped Ray escape from prison?. . 11. Who telephoned for and picked up Ray's duplicate Alabama driver's license from the Birmingham rooming house? . . 13. Was the diversion of Memphis police, moments after the assassination, by a "fake" chase of a white Mustang really a prank?. - 16. How was he able, almost effortlessly, to rent a room that overlooked King's motel-room door? 17. Who led him to the perfect hiding place in Toronto? 18. Why did Ray pick, as aliases, the names of three men living in the Toronto area, none holding a passport and all resembling him? 
ACT II

SCENE 3

Open curtain. Downstage left CORA and MARTHA, a worn Negro maid who is RANDEL'S mother, are returning from the grocery store. CORA is carrying her basket of vitals. MARTHA carries a small bundle of vegetables and a pocket purse.

CORA: I'm staying. Living in the ghetto is giving our entire family insight we'd never known before. It's giving our children valuable background.

MARTHA: That so dear? Maybe you oughta send your chillen to reform school. They'd get the same background there.

CORA: Martin needs me.

MARTHA: That may be. But believe me, if ah had yer money ah'd leave this city. An' you wouldn't catch me vacationin' in no ghetto.

CORA: We'll work together. We'll make this ghetto a better place.

MARTHA: Been like this ever since I lived here... 'til you moved in. An when you leave ah bet Mister Baird, takes the paint right off de walls.l

(CORA fidgets.)

CORA: Martha, we have a plan.

MARTHA: Plannin' • plannin' don't work well here.

CORA: We're going on a strike... a rent strike.

MARTHA: A rent strike? Lord knows ah understand what rent is--ah hundred dollars each payday fer nearly nothin'. But what you talkin' about this strike. Maids can't go on strike. Besides strikin' would give Mister Baird trouble. Wouldn't like troublin' Mister Baird.?

CORA: Trust me. 
${ }^{1}$ David I. Lewis, King: A Critical Biography (New York: Praeger Pub., 1970), p. 313.

"I have never seen such hopelessness," Hosea Williams confessed after a month in the city. "The Negroes of Chicago have a greater feeling of powerlessness than any I ever saw. They don't participate in the governmental process because they're beaten down psychologically."

2 Thomas B. Morgan, "Requiem or Revival," Look, June $14,1966, \mathrm{p} .72$.

"If the people in this block get together... they can change these things. Why don't you come . . tonight and complain?"

"Complain? I didn't know you could complain... that would get my landlord in trouble." 
MARTHA: You mean well, Can't see no other reason for givin' up a neat home bordered with flowers for a ghetto flat.

CORA: Would you make this ghetto beautiful if you could?

MARTHA: Give up tryin' long ago.

CORA: If you could would you make Lawndale bloom?

MARTHA: If I could?

CORA: Then I want you to do the people of Lawndale a favor. I want you to pay your rent to Martin and me, rather than Mister Baird.

MARTHA: To you?

CORA: We're collecting rent from the tenants. Martin will see to it that the rent is used to clean and renovate this building. If there is any money left it will be turned over to Mister Baird. 3

MARTHA: The Reverend King, is he askin' me to break the law?

CORA: Martin says it's above the law. ${ }^{4}$

MARTHA: Nevuh mind. Don't make no difference. Law don't help me none.

CORA: Martin says we're not dealing with the legality of it. We're dealing with the morality of it. The moral issue is far more important than the legal one. 5

MARTHA: Ah knew that all along . . But ah'd lose my job. CORA: You can clean up the flats. . for pay until you find another job. 6

MARTHA: Another job. . another job. An been workin' for Mister Baird for twenty years. He pays good enough. Jobs ain't that easy to come by. (Pause.) It's workin' for Mister Baird that's puttin' Randel through college.?

CORA: There are ten thousand boys like Randel in slums. Most of them won't make it through high school. They'll quit school to help support the family. Or they'll drop out seeing that even with an education ghetto Negroes do menial labor. This environment--this ghetto must be restructured. 

p. 18 .

3"Chicago, Render unto King," Time, March 25, 1966,

All that the five families in the building had to do was to hand their rent over to King instead of the landlord, the Negro leader explained, and he would use it to renovate the place and turn the balance over to the owner. Conceding that this might be considered "supralegal," King contended: "We aren't dealing with the legality of it. We are dealing with the morality of it."

${ }^{4}$ Lewis, King: A Critical Biography, p. 317.

"I won't say that it is illegal," Martin scholasticized, "but I would call it supralegal. The moral question is far more important than the legal one."

5 "Chicago, Render unto King," p. 18.

$\sigma_{\text {William Robert Miller, Martin Luther King, Jr. }}$ (New York: Weybright and Taliey, 1968), p. 238.

The gesture [the trusteeship] was in line with a broad plan to organize work crews to perform repairs and janitorial services, recruiting these men from the unemployed and paying them out of rents withheld from slumlords.

7 "Dr. King Occupies a Flat in Slums," New York Times, 27 January 1966, sec. 1, p. 37.

They [organizers] called on . . [a] wife of a store manager. . and found that she was receptive but cautious.

"If you have something to lose, you think twice," she said.

Her chief concern appeared to be a good high school education for her daughter. 
MARTHA: You believe you can change the ghetto. You might. But I don't think so.

CORA: We can do it. All of us--the people who live in these unhealthy buildings . . But we must be willing to sacrifice.

MARTHA: Randel's my son. Ah get my son educated an' he can walk outa this ghetto.

CORA: Have you talked with your son? He says he's staying. He plans to rebuild this ghetto.

MARTHA: Young fool.

CORA: Your son has character.

MARTHA: I know. I know! Young fool.

CORA: Because he has character, he's sticking to Lawndale. The only way you can help your son is to rebuild this ghetto.

(Pause. Then MARTHA opens her purse and counts out eight tens, one five, four dollars, two quarters, four dimes, and two nickles. She puts the money in CORA'S hand, gazes at it, then exits, stage right. CORA looks at the money for awhile, then exits, stage left.) 
Fade in setting: Baird's apartment, stage right. It is clean, neat, stately, and tasteful. Enter stage right MR. BAIRD. He stops and looks at Lawndale, through an imaginary window; nervously he fumbles a pencil. Enter same entrance, MARTHA, clad for housework.

MARTHA: Mornin' Mister Baird.

(BAIRD glares out the window at Lawndale.)

BAIRD: Didn't expect you today.

MARTHA: What do you mean?

(BAIRD turns to MARTHA)

BAIRD: You know damn well what I mean. Three civil rights groups are collecting what is mine--my cash from my tenants. 1 Your neighbor--the Doctor King--commands one of those civil rights groups. It's theft!

MARTHA: This mornin', as I left, they was exterminatin' the cockroaches in mah kitchen. Never thought I'd live without cockroaches.

BAIRD: And you're a thief.

MARTHA: Shouldn't nobody hafta raise chillen with cockroaches.

BAIRD: I've paid you what the job market demands for domestic labor. I even give you a bonus annually.

MARTHA: Yes, suh. You been a good employer.

BAIRD: So you steal from me. 
${ }^{1}$ David I. Lewis, King: A Critical Biography (New York: Praeger Pub., 1970), p. 317.

Announcing that they were placing the building in "trusteeship," three civil rights groups (the SCLC, the CCCO, and the West Side Federation) assumed the responsibility for the collection and application of the rents of the four families residing in the slum building owned by John Bender. . . . 


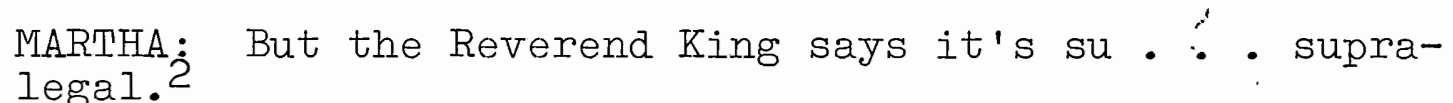
BAIRD: I won't have a thief working in my home.

MARTHA: Suh, ah . •

BAIRD: Leave.

(Gathering her things, MARTHA exits, upstage right. She brushes past plainclothesman TULLEY who is just arriving. TULLEY watches MARTHA exit sensing something is wrong. Then TULLEY knocks.)

TULLEY: Mister Baird?

BAIRD: Yes.

TULLEY: I hope I didn't arrive at an inopportune time. BAIRD: You did. Who are you?

TULLEY: (shows badge) I'm Officer Tulley from downtown. May I come in?

BAIRD: Yes.

(TULLEY enters.)

TULLEY: I'm afraid my visit isn't for pleasant purposes, Mister Baird.

BAIRD: It hasn't been a pleasant day, Officer Tulley. TULLEY: I've been sent to issue you a summons. The city is suing you.

BAIRD: Suing!:

TULLEY: The city of Chicago is charging you with twentythree violations of the building code.3

(TULLEY hands BAIRD the summons. BAIRD refuses to take it.) 
$2_{\text {Tbid. }}$

"I won't say that it is illegal," Martin scholasticized, "but I would call it supralegal. The moral question is far more important than the legal one."

3 "Dr. King Barred From Slum Flats," New York Times, 6 April 1966, sec. 1, p. 28.

The city has sued Mr. Bender, charging 23 code violations and asking that he be fined $\$ 200$ a day for each violation until the needed repairs are made. The case is scheduled to be heard Thursday. 
BAIRD: They can't sue me!

(TULLEY stuffs the summons into BAIRD'S shirt pocket.)

TULLEY: The city asks that you be fined two hundred dollars a day for each violation until the needed repairs are made. ${ }^{4}$

BAIRD: I've supported winning candidates vigorously. That type of dedication has its rewards.

TULLEY: Are you threatening city hall, Mister Baird?

(BAIRD eyes TULLEY.)

TULLEY: (continues) If you don't comply with housing laws, you can expect to be prosecuted in a just city.

BAIRD: The landlords who own the tenant buildings adjacent to mine aren't being sued. Their apartments are in as poor a condition as mine. But I have the Doctor Martin Luther King for a renter. Therefore, I should have expected to be prosecuted in this city. It isn't just. But then it never has been, has it, officer?

TULLEY: The Mayor must crack down.

BAIRD: I see.

DULLEY: The Mayor is a moral man.

BAIRD: I am pleased the Mayor is a moral man, because I have a complaint to voice. You see, a Reverend tenant of mine is stealing from me.

TULLEY: You're questioning the legality of Doctor King's trusteeship. Officially the city views this as a private matter between the parties concerned: you and the Reverend King. 5

BAIRD: And unofficially?

TULLEY: I'm an official representative, Mister Baird. BAIRD: If you were an unofficial representative what would you tell me? 
${ }^{4}$ Ibid.

5Lewis, King: A Critical Biography, p. 318.

- as for the legality of the trusteeship, it [the city] professed to regard this as a private matter between the parties concerned. On the other hand, city hall instructed its allies to attack the legality of the trusteeship. 
TULLEY: If I said that city hall has instructed its allies to attack the legality of the trusteeship and it leaked to the press I'd be back beating the street. 6 That's all, Mister Baird.

(TULLEY begins exit, upstage right, then stops, looks over his shoulder at MISTER BAIRD.)

TULLEY: Be strong.

(TULLEY exits. BAIRD gazes out the window at Lawndale.)

BAIRD: This rotting system and that idealistic black preacher are blood enemies. Except . . except when it comes to sacrificing my whițe hide.

(BAIRD laughs bitterly. Fade lights on BAIRD. MARTIN enters his flat from upstage left.) 
${ }^{6}$ Ibid. 
Spotlight appears on a WHITE IAWYER, facing audience stage right apron. BLACK JUDGE enters stage left and positions himself center stage.

WHITE LAWYER: Seekers of order and obedient souls, Mister Baird who is my client is asking only for what is legally and rightfully his. As a landlord he expects rent from his tenants. Surely his expectations are not unreasonable. If his tenants are dissatisfied.with their dwellings they should make their demands in a more appropriate way than by refusing to pay rent. They should have brought their grievances to a courtroom in the first place. Instead my client has.

The Reverend King could learn much from my client about obeying laws. According to the Reverend King's words and actions, bad laws should be disobeyed. What's worse, he's seized the right to personally judge whether a law is good or bad. Such thought is autocratic, not democratic. Such thought violates the principle of obedience to government. Imagine the chaos if each person chose to obey only the laws which he personally felt were right. Why you couldn't cross the street for fear a driver of an automobile might decide a particular stop light was unnecessary.

Perhaps the Reverend King would argue that in the United States the Negro experiences two faces of the law--a white-faced law and a black-faced law. If so, then we should remind the Reverend King that he is in a new environment. He no longer has to move to the rear of the bus. For the Reverend King is in Chicago where the law has only one face. No one is above the law here. Not even the Reverend King.

If obedience means anything, and it must if our government is to survive, this court has no choice but to enjoin the Reverend Martin Iuther King to relinquish his trusteeship.

(Fade out spot on WHITE LAWYER. Fade up spot on BLACK LAWYER who faces audience stage left apron.)

BLACK LAWYER: Seekers of justice, harsh realists, these tenants who are my clients ask only for what is legally and rightfully theirs. A tenant expects an apartment that meets 
the safety and sanitation codes of this.. northern city. Surely such expectation is not unreasonable. Why even the honorable counsel for Mister Baird has not disagreed with our motives. What he has disagreed with is our means--the rent strike. In fact he has offered an alternative means which certainly my clients weighed before they withheld rent in order to make repairs. Like counsel for Mister Baird my clients wondered if they should take their problems to court. They asked themselves which problems tenants should take to court. Safety problems they wondered? Chicago has fire codes. Then, sanitation problems? Chicago has sanitation codes. They realized that the laws already exist. To make sure they went down to city hall. And sure enough they found the laws there written on paper. But when they came home to Lawndale they couldn't find those laws. They found the violation of those laws. Why? Because in the ghetto, city safety codes and sanitation codes are paper laws. 1

Counsel for Mister Baird tacitly agrees with our motives-namely getting what is rightfully ours. But the alternative means counsel for Mister Baird recommends--the law--hasn't worked. Laws exist! My clients chose to enact existing laws. They chose to fix up their apartments to legal standards. It is fair business practice that the landlord pay for that expense. After all, it's what the law states--the law which counsel for Mister Baird has so much respect for.

Your Honor, if this court enjoins Doctor King from withholding rent it encourages the city of Chicago to neglect the enforcement of law in the ghetto. It is Chicago and not Doctor King that should be on trial here.

(Fade out spot on BLACK LAWYER. Fade up lighting on BLACK JUDGE, and BAIRD and DOCTOR KING. The JUDGE, dressed in judge's garb, stands upstage from the two lawyers. BAIRD and KING stand each in his own apartment facing each other.)

JUDGE: I've listened to the testimony. And I conclude that the withholding of the rent by the trusteeship is theft. I therefore enjoin the Reverend Doctor King to relinquish his trusteeship. The laws of theft are as important to Negroes as they are to anyone else.2,3

(Fade out light on JUDGE. Fade in lights on KING and BAIRD. EXit ATTORNEY'S and JUDGE.) 


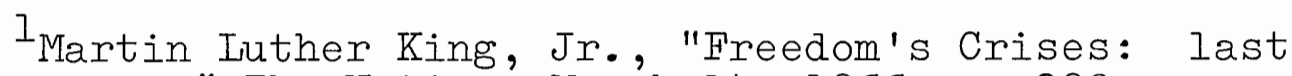
steep ascent," The Nation, March 14, 1966, p. 290.

- . the ordinary Negro, though no social or political analyst, will be skeptical. He knows how many laws exist in Northern states and cities that prohibit discrimination in housing, in education and in employment; he knows how many overlapping commissions exist to enforce the terms of these laws-and he knows how he lives. The ubiquitous discrimination in his daily life tells him that more laws on paper, no matter how breath-taking their terminology, will not guarantee that he will live in a "masterpiece of civilization."

2David I. Lewis, King: A Critical Biography. (New York: Praeger Pub., 1970), p. 318 .

Federal District Court Judge James B. Parson, a black, vigorously denounced the seizure. "I don't think it is legal; it is theft," he fumed.

${ }^{3}$ William Robert Miller, Martin Luther King, Jr. (New York: Weybright and Taliey, 1968), p. 238.

Sued by the owner on April 5, [1966] he was enjoined by the court to relinquish his trusteeship. 
BAIRD: You've lost.

MARTIN: You've been forced by a court order to fix your tenant building to city safety and sanitation laws.

BAIRD: One match box out of a slum of match boxes. If you move from complex to complex, maybe in a quarter of a century you'll win. Face reality, Doctor. You've lost.

MARTIN: We've only lost a legal skirmish. I've never said that the trusteeship was legal. But I have said that it's supralegal. The moral question is far more important than the legal one.

BAIRD: But Reverend, the legal war indicates the power of the battalions.

MARTIN: Mister Baird, the alternative to winning Negro freedom is violence and hate. If non-violence does not win human rights for Negroes in Chicago no one wins.

(Fade out lights on MISTER BAIRD who exits upstage right.) 
ACT II

SCENE 6

It is late at night. MARTIN sits down at his ghetto apartment table and fumbles his coffee cup. A ooffeepot, two cups, and a pitcher of cream sit on the table. There is a knock and we see RANDEL in the living room doorway.

MARTIN: You look troubled. Come on in.

(MARTIN pulls out a chair for RANDEL.)

MARTIN: Have some coffee. ${ }^{1}$

(RANDEL pours himself a cup of coffee and sits down.)

MARTIN: What's on your mind?

RANDEL: I've been thinking about yesterday.

(Screen shows several still pictures from Chicago marches during the conversation.)

MARTIN: Our march on Gage Park?

RANDEL: Yes. Yesterday you marched on white suburbia in Chicago. You marched non-violently. And I marched too. A lot of us marched. We believed non-violence was worth trying.

MARTIN: And we must keep trying until we totally succeed.

RANDEL: The cops showed--to protect you. And those middleclass white home owners came. They came jeering us, throwing their bottles and waving their Nazi flags. They came to hate you.

MARTIN: We will overcome their hate with non-violence. 
${ }^{{ }^{C}}$. Eric Lincoln, ed., Martin Luther King, Jr.: A Profile (New York: Hill and Wang, 1970), p. 168.

Over cups of coffee in my apartment in Chicago, I have often talked late at night and over into the small hours of the morning with proponents of Black Power . . . 
RANDEL: Late in the cold evening we left Gage Park. We left whimpering like

MARTIN: We left non-violently victorious.

RANDEL: Victorious! Where lies the victory? Look! Look out there! That white ghetto wall... (Short wall divides upstage, between BAIRD right, and KING left.) Gage Park still stands. It traps us in poverty . . high rent . . inadequate schools . . low-paying jobs.

MARTIN: Non-violent marches in Chicago have seeded a housing agreement. If signed, the housing agreement will be the strongest step toward open housing taken in any city in the nation.

RANDEL: If signed, it will be another law unenforced by ghetto cops. Gage Park is an iron wall cemented in the core of this city's power structure. Martin, Chicago's mayor isn't Jim Clark. Chicago's mayor isn't Bull Conner. Chicago's mayor is the sophisticated house nigger of white power--a Northern cracker.

ON SCREEN MALCOLM: Northern crackers smile in your face and show you their teeth and they stick the knife in your back when you turn around. 3

MARTIN: The resistance we now face in Chicago cannot solely be attributed to the sophistication of some Northern whites who are racists.

RANDEL: That's not as true as you believe.

MARTIN: In the South the practical cost of change was cheap. . . limited reform . . bargain rates. No expenses and no taxes are required, for Negroes to share lunch counters. 4

RANDEL: I don't want to eat with Whitey. I just want out of his ghetto.

MARTIN: My point is that the sacrifice which is required in order for us to win in this ghetto is greater than the sacrifice which was required to win in the South. Even the more significant changes in the South like voter registration required neither large monetary nor psychological sacrifice. 5

RANDEL: What of dignity? You laid black children on the line in Selma. And what happened? Those political crackers threw black babes in jail. 
2 Martin Luther King, Jr., Where Do We Go From Here: Chaos or Community (New York: Harper and Row, 1967), p. 58.

Our non-violent marches in Chicago last summer brought about a housing agreement which, if implemented, will be the strongest step toward open housing taken in any city in the nation.

${ }^{3}$ Malcolm X, Malcolm X Speaks, ed. George Breitman (New York: Grove Press, 1965), p. I10.

- . these Northern crackers smile in your face and show you their teeth and they stick the knife in your back when you turn around.

${ }^{4} \mathrm{King}, \mathrm{p} .5$.

The practical cost of change for the nation up to this point has been cheap. The limited reforms have been obtained at bargain rates. There are no expenses and no taxes are required, for Negroes to share lunch counters

5 Ibid.

Even the more significant changes involved in voter registration required neither large monetary nor psychological sacrifice. . . As the nation passes from opposing extremist behavior to the deeper and more pervasive elements of equality, white America reaffirms its bonds to the status quo. 
MARTIN: We won voting rights in Selma. The sacrifice was small when compared to what we gained.

RANDEL: Black dignity is no small sacrifice.

MARTIN: What is the alternative to non-violent sacrifice? Watts! In one night of rioting in Watts, more people were killed than in ten years of non-violent demonstration across the South. 6

RANDEL: Non-violence has not won in the ghetto. Other than a housing bill that is not yet enacted, and the minute gains you've made through rent strikes and boycotts, name your success here--in Lawndale.

MARTIN: Success comes harder here. Here, in the ghetto, white America reaffirms its bonds to the status quo.

RANDEL: You've named our enemy--white America. You see the truth. Why do you continue preaching non-violence?

MARTIN: The truth I see is you. You frighten me.

ON SCREEN MALCOLM: We have a common enemy.?

MARTIN: Disappointment produces despair. 8

ON SCREEN MALCOLM: We have this in common: ${ }^{9}$

MART IN . . despair produces bitterness. 10

ON SCREEN MALCOLM: We have a common oppressor, a common exploiter, and a common discriminator. Once we all realize that we have a common enemy, then we unite on the basis of what we have in common. 11 MARTIN: The one thing certain about bitterness is its
blindness.12

ON SCREEN MALCOLM: And what we have foremost in common is that enemy--the white man. He's enemy to all of us.13

MARTIN: Bitterness has not the capacity to make the distinction between some and all. When some members of the dominant group, particularly those in power, are racist in attitude and practice, bitterness accuses the whole group.

ON SCREEN MALCOLM: I know that some of you all think that some of them aren't enemies. Time will tell.14 
$6_{\text {King, Where Do We Go From Here: }}$ p. 58.

Fewer people have béen killed in ten years of nonviolent demonstrations across the South than were killed in one night of rioting in Watts.

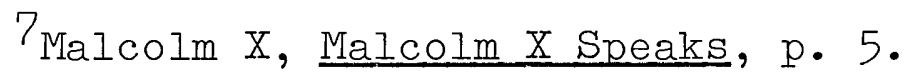

We have a common enemy. We have this in common: We have a common oppressor, a common exploiter, and a common discriminator. But once we all realize that we have a common enemy, then we unite--on the basis of what we have in common. And what we have foremost in common is that enemy--the white man. He's an enemy to all of us. I know some of you all think that some of them aren't enemies. Time will tell.

$8_{\mathrm{King}}, \mathrm{p} .26$.

- . disappointment produces despair and despair produces bitterness, and that the one thing certain about bitterness is its blindness. Bitterness has not the capacity to make the distinction between some and all. When some members of the dominant group, particularly those in power, are racist in attitude and practice, bitterness accuses the whole group.

\footnotetext{
${ }^{9}$ Malcolm X, p. 5 .

$10_{\text {King, }}$. 26.

$11_{\text {Malcolm } \mathrm{X}, \mathrm{p} .} 5$.

$12_{\mathrm{King}}, \mathrm{p} \cdot 26$.

13 Malcolm X, p. 5 .

14 Tbid.
} 
RANDEL: But Nazi flags are in Gage Park.

ON SCREEN MALCOLM: You're in a society that's just as capable of building gas ovens for black people as Hitler's society was ...15

MARTIN: White and blacks together will tear down Nazi flags. Together we tore Nazi gas ovens apart.

ON SCREEN MALCOLM: It's just like when you've got some coffee that's too black, which means it's too strong. What do you do? You integrate it with cream. You make it weak.16

(RANDEL pushes the cream at MARTIN. MARTIN looks at RANDEL then deliberately pours a measured amount of cream into the coffee.)

ON SCREEN MALCOLM: But if you pour too much cream in it you won't even know you ever had coffee. It used to be hot, it becomes too cool. It used to be strong, it becomes weak. I?

MARTIN: The coffee and the cream mix. It is a scientific law that they will. And in this age it is a spiritual law that they must. Ten percent of the population cannot by 18 tensions alone induce 90 percent to change a way of life. ${ }^{18}$

RANDEL: I am black. Therefore I exist in a trap. That's the application of scientific law in America. If we can find no other road to freedom, we must tear America apart by any means necessary.

MARTIN: Your belief is understandable as a response to a white power structure that never completely committed itself to true equality for the Negro. Your belief is understandable as a response to a die-hard mentality that sought to shut all windows and doors against the winds of change. But at bottom you believe that American society is so hopelessly corrupt and enmeshed in evil that there is no possibility for salvation from within. Beneath all the satisfaction of a gratifying slogan, Black Power is a nihilistic philosophy born out of the conviction that the Negro can't win.19

RANDEL: Non-violence hasn't beat this ghetto. Martin, it was a mistake for you to come live in Chicago's ghetto. You won't face agitation. If you won't listen to me, listen to history. Listen to the words of Frederick Douglass. Douglass said, those who deprecate agitation want crops without 
15Malcolm X, Malcolm X Speaks, p. 168. Speech by Malcolm X, February 14, 1965 at a meeting in Detroit sponsored by the Afro-American Broadcasting Company.

You're in a society that's just as capable of building gas ovens for black people as Hitler's society was . . .

16 Tbid., p. 16. "Message To the Grass Roots" by Malcolm $X$ given in late 1963 in Detroit at King Solomon Baptish Church.

It's just like when you've got some coffee that's too black, which means it's too strong. What do you do? You integrate it with cream, you make it weak. But if you pour too much cream in it, you won't even know you ever had coffee. It used to be hot, it becomes cool. It used to be strong, it becomes weak

17

Tbid.

18King, Where Do We Go From Here: p. 51.

Ten percent of the population cannot by tensions alone induce 90 percent to change a way of life.

${ }^{19}$ Ibid., p. 44.

Beneath all the satisfaction of a gratifying slogan, Black Power is a nihilistic philosophy born out of the conviction that the Negro can't win. 
plowing up the ground; rain without thunder and lightning; the ocean without the roar of its many waters. Frederick Douglass was describing you, Martin. Power concedes nothing without demand. 20 You're afraid of agitation.

MARTIN: I don't fear agitation. I fear violent agitation. Violence agitates the fears of the white majority and leaves them less ashamed of their actions. 21 Non-violence agitates conscience and morality. Weigh the wisdom of Booker T. "22
Washington, "Let no man pull you so low as to hate him.

RANDEL: I don't love my oppressor. Look around you. Look at the roaches. Smell the urine in the hall. This ghetto does not function by non-violence, morality, or love, but by power. 23

MARTIN: Be careful that you don't seek that power for power's sake. If we seek power to make the world and our nation a 24
better place to live, violence can never provide the answer.

RANDEL: But non-violence here is no power at all.

MARTIN: Randel, have faith. Have faith and we shall overcome.

RANDEL: Have faith in the innate conscience of white America?

MARTIN: You must.

(MARTIN moves to the window and looks at the ghetto wall.)

MARTIN: Look out there.

(RANDEL moves to the window and looks at the ghetto wall.)

MARTIN: The obstacle--the ghetto wall crumbles slowly. Notice the foundation of the wall. Sacrifice wears at the foundation. Non-violence erodes the base hostilities. If the sacrifice was greater or the need for sacrifice less, the wall would wear more quickly. But the ghetto wall crumbles slowly. And so my senses have expanded ten thousand thousands in matters of color. Color--the word must carry more meaning than it should today. Today my eyes see beyond my heart. 
${ }^{20}$ Stokely Carmichael and Charles V. Hamilton, Black Power: The Politics of liberation in America (New York: Random House, 1967), p. x.

- . we would suggest a more meaningful language, that of Frederick Douglass. . .

Those who profess to favor freedom yet deprecate agitation, are men who want crops without plowing up the ground; they want rain without thunder and lightning. They want the ocean without the awful roar of its many waters.

-. Power concedes nothing without demand.

${ }^{21}$ King, Where Do We Go From Here:, p. 61.

The problem with hatred and violence is that they intensify the fears of the white majority, and leave them less ashamed of their prejudices toward Negroes.

22 David I. Lewis, King: A Critical Biography

(New York: Praeger Pub., 1970), p. 162.

Once again [this time in Albany] as in Montgomery he [Martin Iuther King] quietly admonished his followers in the words of Booker T. Washington. "Let no man pull you so low as to make you hate him:"

23 Stokely Carmichael, Stokely Speaks: Black Power Back to Pan-Africanism (New York: Random House, 1971), p. 19.

We had to work for power, because this country does not function by morality, love, and nonviolence, but by power.

$$
{ }^{24} \mathrm{King}, \mathrm{p} .62 .
$$

Are we seeking power for power's sake? Or are we seeking to make the world and our nation better places to live? If we seek the latter, violence can never provide the answer. 
(Fade in picture of MALCOLM on screen.)

MARTIN: (continuing) And now it seems my words ring on dead ears. Was it the same for Malcolm? Upon your return from your pilgrimage in Mecca your words rang strange to many.

ON SCREEN MALCOLM: In the past, I have permitted myself to be used to make sweeping indictments of all white people, and these generalizations have caused injuries to some white people who did not deserve them. Because of the spiritual rebirth which I was blessed to undergo as a result of my pilgrimage to the Holy City of Mecca, I no longer subscribe to sweeping indictments of one race. My pilgrimage to Mecca served to convince me that perhaps American whites can be cured of rampant racism which is consuming them and about to destroy this country. In the future I intend to be careful not to sentence anyone who has not been proven guilty. I am not a racist and do not subscribe to any tenants of racism. In all honesty and sincerity it can be stated that I wish nothing but freedom, justice and equality, life, liberty and the pursuit of happiness--for all people. My first concern is with the group of people to which I belong, the Afro-Americans, for we, more than any other people, are deprived of these inalienable rights. 25

\section{(Fade out MALCOLM.)}

MARTIN: It is difficult knowing that this ghetto exists.

RANDEL: It exists.

MARTIN: But it does. Here I stand in the depths of a poverty striken Chicago slum which systematically imprisons a race in ignorance and poverty. God, am I helpless against the forces of evil. It can't be. Yet, it appears that the white segregationists and the ordinary white citizen have more in common with one another than either have with the Negro. 26

(Pause.)

MART IN: It beckons me. 
25 Malcolm X, Malcolm X Speaks, pp. 58-59.

Two days after his [Malcolm's] return [5/24/64 from his pilgrimage to Mecca] he said in a speech in Chicago:

"In the past, I have permitted myself to be used to make sweeping indictments of all white people, and these generalizations have caused injuries to some white people who did not deserve them. Because of the spiritual rebirth which I was blessed to undergo as a result of my pilgrimage to the Holy City of Mecca, I no longer subscribe to sweeping indictments of one race. My pilgrimage to Mecca served to convince me that perhaps American whites can be cured of the rampant racism which is consuming them and about to destroy this country. In the future, I intend to be careful not to sentence anyone who has not been proven guilty. I am not a racist and do not subscribe to any of the tenets of racism. In all honesty and sincerity it can be stated that I wish nothing but freedom, justice and equality: life, liberty and the pursuit of happiness--for all people. My first concern is with the group of people to which I belong, the Afro-Americans, for we, more than any other people, are deprived of these inalienable rights."

26 King, Where Do We Go From Here:, p. 4.

It appeared that the white segregationist and the ordinary white citizen had more in common with one another than either had with the Negro. 
RANDEL: Surely it can't be success that beckons you. MARTIN: Blood. I'm afraid. I'm afraid you smell of it. (Moving downstage, MARTIN exits the living room. RANDEL stands a moment, then exits after MARTIN.) 
ACT II

SCENE 7

DOCTOR KING followed by RANDEL walk toward Gage Park Border, center stage. 1

ON TAPE OLD WHITE MAN: I worked all my life for a house out here and no nigger's going to get it!?

(RANDEL flings up his arms to protect his face. Sound of bottle crashing on the pavement. Lights fade in on a WHITE HOUSEWIFE and a REPORTER on Gage Park side apron, stage right. The REPORTER points a microphone at the HOUSEWIFE.)

WHITE HOUSEWIFE: No one was prejudiced against the Northern Niggers. It's the Southern ones.3

(MARTIN and RANDEL cross the border and move into Gage Park, stage right center. They head downstage right, slowly.)

ON TAPE YOUTH: We want Martin Luther coon. ${ }^{4}$

WHITE HOUSEWIFE: (continuing) The northern niggers were satisfied until that Luther King brought in his trouble makers from the South.5

(Fade out lights on WHITE HOUSEWIFE and REPORTER. Cut in sound of TEENAGERS chanting.)

ON TAPE TEENAGERS CHANT ING: Hate! Hate! Hate! 6

(On screen slide or film: MAYOR DALEY promises to end ghettos. Recording is necessary.?)

MARTIN: The mayor has just been re-elected. 8 
I"Chicago, the touchiest target," Newsweek, August 15, 1966, p. 29.

One angry flare-up came the third day out, when police (who claimed they had only an hour's notice from King's staff) dispatched a thin crew to escort the marchers through a mob of 1,000 in Gage Park.

2 "Rock Hits Dr. King As Whites Attack March in Chicago," New York Times, 6 August 1966, sec. 1, p. 4.

One elderly man went around addressing small groups. "I worked all my life for a house out here," he said to anyone who would listen, "and no nigger is going to get it."

${ }^{3}$ Paul Good, "Bossism, Racism and Dr. King," The Nation, September 19, 1966, p. 241.

The New York Times quoted a lady hardware clerk:

No one was prejudiced against the Northern niggers. It's the Southern ones. The Northern niggers were satisfied until that Iuther King brought in his trouble-makers from the South.

4 "Rock Hits Dr. King," p. 4.

5 Good, p. 241.

$6_{\text {Ibia. }}$

"Hate, hate, hate!" chanted a group of teenagers.

7 "Daley Elected by Wide Margin to 4 th Term as Chicago Mayor, " New York Times, 5 April 1967, sec. 1, p. 30.

In a victory statement, Mr. Daley pledged to eliminate "every slum in the city" by the end of this year and to provide equality of opportunity in jobs, schools, housing and recreation.

$8_{\text {Tbid. }}$ 
(RANDEL drops back increasing the distance between himself and MARTIN.)

MARTIN: Come close, Randel. Watch close.

(RANDEL does not come close. Fade under chanting as MART IN then RANDEL start walking back toward the border between the black ghetto and Gage Park, center stage.)

ON TAPE: We want Martin Luther coon. 9

MARTIN: Caravans will set out for Washington from ten cities and five rural districts. One of the caravans will start out from Lawndale.10

RANDEL: The march on Washington?

MARTIN: The poor peoples march. We will place the problems of the poor at the seat of the government of the wealthiest nation in the history of mankind. 11

RANDEL: Your poor peoples march will include whites?

MARTIN: Millions of underprivileged whites are considering the contradiction between segregation and economic progress. 12

RANDEL: I can't be with you.

(Tape background fades out as MARTIN, then RANDEL arrive on the border farther downstage than when they first crossed the border and noticeably farther apart.)

MARTIN: The flash point of rage is close at hand.

RANDEL: The ghetto still stands.

MARTIN: A living ghetto breathing, proving there is no separate white path to power and fulfillment short of social disaster that does not share that power with black aspirations for freedom and human dignity. Can you know that?

RANDEL: I know.

MARTIN: Then know that there is no separate black path to 13 power and fulfillment that does not intersect white paths. ${ }^{13}$ 
9 "Rock Hits Dr. King," p. 4.

${ }^{10}$ David I. Lewis, King: A Critical Biography

(New York: Praeger Pub., 1970), p. 373.

The initial cadres would be drawn from ten cities and five rural districts located . . Chicago's Lawndale community . . .

\section{${ }^{11}$ Ibid.}

"We will place the problems of the poor at the seat of government of the wealthiest nation in the history of mankind," Martin wrote.

$12_{\text {Martin Luther King, Jr., Where Do We Go From Here: }}$ Chaos or Community (New York: 'Harper and Row, 1968), p. 152.

Millions of underprivileged whites are in the process of considering the contradiction between segregation and economic progress.

$$
13 \text { Ibid., p. } 48 .
$$

Yet behind Black Power's legitimate and necessary concern for group unity and black identity lies the belief that there can be a separate black road to power and fulfillment. Few ideals are more unrealistic. 
RANDEL: I know that the ghetto still stands.

MARTIN: Come close. Watch close.

RANDEL: It is enough that I support your views on Vietnam, few do.

MARTIN: Things have been so hard in the North.

RANDEL: Yes, things are hard in the North.

MARTIN: You will follow me to Memphis? We'll be able to do more for the ghetto when we succeed in Memphis.

RANDEL: There is much to be done in the ghetto. I think I'll stay here in the ghetto.

MARTIN: But the test. The test is in Memphis.

RANDEL: (pause) I'll be in Memphis.

(Fade out lights except for a spot on MARTIN. On screen: Memphis during garbage strike.)

MARTIN: And then I got into Memphis, and some began to talk about the threats that were out, or what would happen to me from some of our sick brothers. Well, I don't know what will happen now. We've got some difficult days ahead. But it realiy doesn't matter with me now. Because I've been to the mountain top. I won't mind. Like anybody, I would like to live a long life. Longevity has its place. But I'm not concerned about that now. I just want to do God's will. And He's allowed me to go up to the mountain. And I've looked over, and I've seen the promised land. So I'm happy tonight. I'm not worried about anything. I'm not fearing any man. "Mine eyes have seen the glory of the coming of the Lord."14

(Screen cuts out. Spotlight on RANDEI.)

RANDEL: Rise Memphis!

(Fade in lighting on an area downstage right. A non-violent AIDE quickly enters center stage right, joining MARTIN. MARTIN and the AIDE moving downstage right. RANDEL follows close behind. Fade in music and song "We Shall Overcome.") 
14 William Robert Miller, Martin Luther King, Jr. (New York: Weybright and Taliey, 1968), pp. 275-276.

MASS MEETING AT MASON TEMPLE: "And then I got into Memphis, and some began to talk about the threats that were out, or what would happen to me from some of our sick brothers. Well, I don't know what will happen now. We've got some difficult days ahead. But it really doesn't matter with me now. Because I've been to the mountain top. I won't mind.

"Like anybody, I would like to live a long life. Longevity has its place. But I'm not concerned about that now. I just want to do God's will. And He's allowed me to go up to the mountain. And I've looked over, and I've seen the promised land.

"I may not get there with you, but I want you to know tonight that we as a people will get to the promised land.

"So I'm happy tonight. I'm not worried about anything. I'm not fearing any man. 'Mine eyes have seen the glory of the coming of the Lord. " 
RANDEL: (shouts) If you expect honkies to get the message you got to break some windows. 15

(RANDEI breaks through the arms of KING and the AIDE, and exits downstage right running. Sound: crashing glass. Fade in street disorder background.) AIDE: Go back to the church! . Most of them are going
back. But some are staying.16

MARTIN: Tear gas.

AIDE: The mood is getting angrier.

MARTIN: If I could speak . .

AIDE: It's no use.

(Gunshot.)

AIDE: God no! Can it be!

MARTIN : What?

AIDE: A policeman has shot a black youth. 17

MARTIN : No:

AIDE: I've got to get you out of here!

(The AIDE moving stage left, leads a stunned MARTIN through a medley of riot sounds and flashes. Meanwhile, a spotlight cuts on JAMES EARL RAY, downstage left, who is aiming his rifle at MARTIN. Gunshot. Sound effects die at gunshot. All characters freeze on stage as MARTIN drops to the ground. Fade under lights. On screen: still of MARTIN LUTHER KING. Play edited speech "I Have A Dream" with the real MARTIN LUTHER' KING'S voice.)

I say to you today, my friends, that in spite of the difficulties and frustrations of the moment I still have a dream. It is a dream deeply rooted in the American dream. I have a dream that one day this nation will rise up and live 
${ }^{15}$ Louis Lomax, Martin Luther King, Jr.: A Profile, ed. C. Eric Lincoln (New York: Hill and Wang, 1970), p. 176.

"Man," snapped one of the tribunal, "if you expect honkies to get the message you got to break some windows."

16 Miller, p. 271.

- - and Lawson addressed the marchers, asking them to go back to the church. Most of them began to do so, but the young black militants defiantly held their ground. In ten minutes a cordon of police closed in with tear gas. The youth fled, but the police found others to attack. They shot one sixteen-year-old boy to death, . .

17 Ibid. 
out the true meaning of its creed. "We hold these truths to be self-evident; that all men are created equal."

I have a dream that one day on the red hills of Georgia the sons of former slaves and the sons of former slave owners will be able to sit down together at the table of brotherhood.

I have a dream that one day even the state of Mississippi, a desert state sweltering with the heat of injustice and oppression, will be transformed into an oasis of freedom and justice.

I have a dream that my four little children will one day live in a nation where they will not be judged by the color of their skin but by the content of their character.

I have a dream today.

I have a dream that one day the state of Alabama, whose governor's lips are presently dripping with the words of interposition and nullification, will be transformed into a situation where little black boys and black girls will be able to join hands with little white boys and white girls and walk together as sisters and brothers.

I have a dream today.

I have a dream that one day every valley shall be exalted, every hill and mountain shall be made low, the rough places will be made plain, and the crooked places will be made straight, and the Glory of the lord shall be revealed, and all flesh shall see it together.

This is our hope. This is the faith with which I return to the South. With this faith we will be able to hew out of the mountain of despair a stone of hope. With this faith we will be able to transform the jangling discords of our nation into a beautiful symphony of brotherhood.

With this faith we will be able to work together, to pray together, to struggle together, to go to jail together, to stand up for freedom together, knowing that we will be free one day.

This will be the day when all of God's children will be able to sing with new meaning, "My country 'tis of thee, sweet land of liberty, of thee I sing. Land where my fathers died, land of the Pilgrims' pride, from every mountainside, let freedom ring."

And if America is to be a great nation, this must become true. So let freedom ring from the prodigious hilltops of New Hampshire. Let freedom ring from the mighty mountains of New York. Let freedom ring from the heightening Alleghenies of Pennsylvania!

Let freedom ring from the snowcapped Rockies of Colorado! Let freedom ring from the curvaceous peaks of California. But not only that; let freedom ring from the Stone Mountain of Georgia! Let freedom ring from the Lookout Mountain of Tennessee!

Let freedom ring from every hill and molehill of Mississippi. From every mountainside, let freedom ring. 
When we let freedom ring, when we let it ring from every village and every hamlet, from every state and every city, we will be able to speed up that day when all of God's children, black men and white men, Jews and Gentiles, Protestants and Catholics, will be able to join hands and sing in the words of the old Negro spiritual, "Free at last! Free at last! Thank God Almighty, we are free at last! "1 8

CLOSE CURTAIN 
18 Martin Iuther King, Jr., "I Have A Dream," The Annals of America (Chicago, William Benton, 1968), 18:158-159. 


\section{A SELECTED BIBLIOGRAPHY}

\section{BOOKS}

Bennett, Lerone. What Manner of Man. Chicago: Johnson Pub., 1968.

Blair, Clay, Jr. The Strange Case of James Earl Ray. New York: Bantam Books, 1969.

Bleiweiss, Robert M., ed. Marching to Freedom. New York: The New American Library, 1969.

Breitman, George, ed. Malcolm X Speaks. New York: Grove Press, 1965.

Carmichael, Stokely and Hamilton, Charles V. Black Power: The Politics of Liberation in America. New York: Random House, 1967.

Clayton, Ed. Martin Iuther King: The Peaceful Warrior. New York: Washington Square Press, 1969.

Goldman, William. Butch Cassidy and the Sundance Kid. New York: Bantam Books, 1969.

King, Coretta Scott. My Life With Martin Luther King, Jr. New York: Holt, Rinehart and Winston, 1969.

King, Martin Iuther, Jr. "I Have A Dream." The Annals of America. Chicago: William Benton, 1968, 18:156-159.

"Letter From Birmingham Jail." The Annals of America. Chicago: William Benton, 1968, 18:143-149.

Strength to Love. New York: Harper and Row, 1968. Stride Toward Freedom. New York: Harper and Row, $\overline{1958 .}$

The Trumpet of Conscience. New York: Harper and Row, 1968. These speeches by Martin Luther King, Jr. were close in time to his assassination.

Where Do We Go From Here: Chaos or Community.

New York: Harper and Row, 1967. 
1964 .

Why We Can't Wait. New York: Harper and Row,

Lewis, David I. King: A Critical Biography. New York: Praeger Pub., 1970.

Lincoln, C. Eric, ed. Martin Iuther King, Jr: A Profile. New York: Hill and Wang, 1970.

Miller, William Robert. Martin Luther King, Jr. New York: Weybright and Taliey, 1968.

Smith, Arthur I. and Robb, Stephen, eds. The Voice of Black Rhetoric. Boston: Allyn and Bacon, 1971.

Smith, Kenneth I. and Zepp, Ira G., Jr. Search for the Beloved Community: The Thinking of Martin Luther King, Jr. Pennsylvania: Judson Press, 1974.

Walton, Hanes, Jr. "The Political Philosophy of Martin Iuther King, Jr." Ph.D. dissertation, Howard University, 1967.

Warren, Mervyn Alonzo. "A Rhetorical Study of the Preaching of Doctor Martin Iuther King, Jr., Pastor and Pulpit Orator." Ph.D. dissertation, Michigan State University, 1966.

Wasserman, Lois Diane. "Martin Luther King, Jr.: The Molding of Non-Violence as a Philosophy and Strategy." Ph.D. dissertation, Boston University, 1972.

\section{FILM}

Martin Luther King, Jr.: from Montgomery to Memphis. Bailey Film Association, 1969.

\section{MAGAZINE ARTICLES}

Cook, Bruce. "King in Chicago." Commonweal, April 29, 1966, pp. 175-177.

Fager, Charles E. "Dilemma for Dr. King." Christian Century, March 16, 1966, pp. 331-332.

Good, Paul. "Bossism, Racism and Dr. King." The Nation, September 19, 1966, pp. 237-242. 
King, Martin Luther, Jr. "Freedom's Crises: last steep ascent." The Nation, March 14, 1966, pp. 288-292.

Leifermann, H. P. "Profession: Concert Singer, Freedom Movement Lecturer." New York Times Magazine,

November 26, 1972, pp. 42-70.

Morgan, Thomas B. "Requiem or Revival?" Iook, June 14, 1966, $\mathrm{pp} .70-73$.

Smith, Donald H. "Martin Luther King, Jr: In the Beginning at Montgomery." Southern Speech Journal, XXXIV (Fall 1968), 12-15.

"A New White Backlash." Saturday Evening Post, September 10, $1966, \mathrm{p} .2$.

"As Negro Unrest Continues to Spread." U.S. News and World Report, July 25, 1966, p. 30 .

"Chicago: Gamble in the Ghetto." Newsweek, January 31, 1966, p. 24 .

"Chicago, Render unto King." Time, March 25, 1966, pp. 18-19. "Chicago, the touchiest target." Newsweek, August 15, 1966, p. 29 .

"Dr. King Carries Fight to Northern Slums." Ebony, April 1966, pp. 94-96.

"Dr. King's Case for Nonviolence." America, November 12, 1966, p. 578.

"Graham and King as Ghetto-Mates." Christian Century, August 10, 1966, pp. 976-977.

"One Last Chance." Christian Century, June 22, 1966, pp. 792793.

"Still King." Christian Century, September 7, 1966, pp. 10711072 .

"Too Many Cooks, Too Much Spice." Christian Century, July 13, 1966, p. 880 . 
NEWSPAPER ARTICLES

King, Martin Luther, Jr. "Another Opinion 'I Oppose the War in Vietnam. " New York Times, 2 April 1967, sec. 4, p. 11 .

Robert, Gene. "Rock Hits Dr. King As Whites Attack March in Chicago." New York Times, 6 August 1966, sec. I, p. 4 .

Robinson, Douglas. "Dr. King Proposes a Boycott of War." New York Times, 5 April 1967, sec. 1, p. 1 .

Wehrein, Austin C. "Dr. King Occupies a Flat in Slums." New York Times, 27 January 1966, sec. 1, p. 37.

"Daley Elected by Wide Margin to 4th Term as Chicago Mayor." New York Times, 5 April 1967, sec. 1, p. 30.

"Dr. King Barred from Slum Flats." New York Times, 6 April 1966, sec. I, p. 28. 